\title{
Vascular endothelial growth factor receptor 3 directly regulates murine neurogenesis
}

\author{
Charles-Félix Calvo, ${ }^{1,2,3,18}$ Romain H. Fontaine, ${ }^{1,2,3,18}$ Jihane Soueid, ${ }^{1,2,3,18}$ Tuomas Tammela, ${ }^{4,5}$ \\ Taija Makinen, ${ }^{4,5}$ Clara Alfaro-Cervello, ${ }^{6}$ Fabien Bonnaud, ${ }^{7}$ Andres Miguez, ${ }^{1,2,3}$ Lucile Benhaim, ${ }^{1,2,3}$ \\ Yunling $\mathrm{Xu}^{8}{ }^{8}$ Maria-José Barallobre, ${ }^{9}$ Imane Moutkine, ${ }^{1,2,3}$ Johannes Lyytikkä, ${ }^{10}$ Turgut Tatlisumak, ${ }^{10}$ \\ Bronislaw Pytowski, ${ }^{11}$ Bernard Zalc, ${ }^{1,2,3,12}$ William Richardson, ${ }^{13,14}$ Nicoletta Kessaris, ${ }^{13,14}$ \\ Jose Manuel Garcia-Verdugo, ${ }^{6,15}$ Kari Alitalo, ${ }^{4,5}$ Anne Eichmann, ${ }^{8,16}$ and Jean-Léon Thomas ${ }^{1,2,3,12,17,19}$ \\ ${ }^{1}$ University Pierre et Marie Curie-Paris 6, Centre de Recherche de l'Institut du Cerveau et de la Moelle Epiniere, UMR S975, \\ Paris 75651, France; ${ }^{2}$ Inserm, U975, Paris 75651, France; ${ }^{3}$ CNRS, UMR 7225, Paris 75651, France; ${ }^{4}$ Molecular/Cancer Biology \\ Laboratory, Biomedicum Helsinki, University of Helsinki, Helsinki FI-00290, Finland; ${ }^{5}$ Department of Pathology, Haartman \\ Institute, University of Helsinki, Helsinki FI-00290, Finland; ${ }^{6}$ Laboratorio de Morfología Celular, Centro de Investigación \\ Príncipe Felipe, CIBERNED, Valencia 46013, Spain; ${ }^{7}$ Cellular Imaging and Analysis, PerkinElmer, Coventry HP9 2FX, United \\ Kingdom; ${ }^{8}$ Center for Interdisciplinary Research in Biology (CIRB), Collège de France, Paris 75005, France; ${ }^{9}$ Center for Genomic \\ Regulation, UPF and CIBER de Enfermedades Raras, Barcelona 08003, Spain; ${ }^{10}$ Experimental MRI Laboratory, Department of \\ Neurology, Helsinki University Central Hospital, Helsinki FI-00290, Finland; ${ }^{11}$ ImClone Systems, New York, New York 10016, \\ USA; ${ }^{12}$ Pitié-Salpêtrière, Assistance Publique-Hôpitaux de Paris (AP-HP), Paris 75651, France; ${ }^{13}$ Wolfson Institute for Biomedical \\ Research, University College London, London WC1E 6BT, United Kingdom; ${ }^{14}$ Research Department of Cell and Developmental \\ Biology, University College London, London WC1E 6BT, United Kingdom; ${ }^{15}$ Laboratorio de Neurobiología Comparada, Instituto \\ Cavanilles, Universidad de Valencia, Valencia 46980, Spain; ${ }^{16}$ Department of Cardiology, Yale University School of Medicine, \\ Connecticut 06511, USA; ${ }^{17}$ Department of Neurology, Yale University School of Medicine, Connecticut 06511, USA
}

Neural stem cells (NSCs) are slowly dividing astrocytes that are intimately associated with capillary endothelial cells in the subventricular zone (SVZ) of the brain. Functionally, members of the vascular endothelial growth factor (VEGF) family can stimulate neurogenesis as well as angiogenesis, but it has been unclear whether they act directly via VEGF receptors (VEGFRs) expressed by neural cells, or indirectly via the release of growth factors from angiogenic capillaries. Here, we show that VEGFR-3, a receptor required for lymphangiogenesis, is expressed by NSCs and is directly required for neurogenesis. Vegfr3::YFP reporter mice show VEGFR-3 expression in multipotent NSCs, which are capable of self-renewal and are activated by the VEGFR-3 ligand VEGF-C in vitro. Overexpression of VEGF-C stimulates VEGFR-3-expressing NSCs and neurogenesis in the SVZ without affecting angiogenesis. Conversely, conditional deletion of Vegfr3 in neural cells, inducible deletion in subventricular astrocytes, and blocking of VEGFR-3 signaling with antibodies reduce SVZ neurogenesis. Therefore, VEGF-C/ VEGFR-3 signaling acts directly on NSCs and regulates adult neurogenesis, opening potential approaches for treatment of neurodegenerative diseases.

[Keywords: adult neurogenesis; neural stem cells; subventricular astrocytes; angiogenesis; lymphangiogenesis; VEGF-C/VEGFR-3]

Supplemental material is available for this article.

Received November 12, 2010; revised version accepted February 24, 2011.

Neural stem cells (NSCs) are self-renewing cells that generate neurons and glia throughout life. NSCs are nested in specialized neurogenic niches of the subventricular zone (SVZ), which lines the cerebral ventricles of the adult mammalian brain. NSCs are a subset of the

\footnotetext{
${ }^{18}$ These authors contributed equally to this work.

${ }^{19}$ Corresponding author.

E-MAIL jean-leon.thomas@yale.edu; FAX (203) 737-6118.

Article is online at http://www.genesdev.org/cgi/doi/10.1101/gad.615311.
}

subventricular astrocytes, also called type B cells, which express the glial fibrillary acidic protein (GFAP) (Doetsch et al. 1999; Garcia et al. 2004; Merkle et al. 2004, 2007; Sanai et al. 2004; Kriegstein and Alvarez-Buylla 2009). NSCs are distinguished from other subventricular astrocytes by their capacity to retain 5-bromo-2'-deoxyuridine (BrdU) for an extended period of time due to their relatively long cell cycle time (Spangrude et al. 1988; Tavazoie et al. 2008). A subset of NSCs, called B1 cells, is identified by the presence of a primary cilium extending 
into the lateral ventricle (lv) (Mirzadeh et al. 2008). NSCs express epidermal growth factor receptor (EGFR) and generate GFAP-negative transit-amplifying precursors (TAPs), which maintain EGFR expression and divide rapidly (Pastrana et al. 2009). TAPs produce glial precursor cells (Cesetti et al. 2009; Gonzalez-Perez et al. 2009; Gonzalez-Perez and Quinones-Hinojosa 2010) as well as doublecortin (DCX)-expressing neuroblasts (also called type A cells) that migrate from the SVZ toward the olfactory bulb $(\mathrm{OB})$, where they differentiate into interneurons and integrate existing neural circuits (Choinacki et al. 2009; Nissant et al. 2009).

NSCs establish intimate interactions with vascular cells to form "neurovascular niches" within the adult SVZ (Mirzadeh et al. 2008; Shen et al. 2008; Tavazoie et al. 2008). The molecular cross-talk between NSCs and endothelial cells includes signals acting on both cell types, such as members of the vascular endothelial growth factor (VEGF) family. In the vascular system, VEGF-A regulates angiogenesis and vascular permeability via its receptors, VEGFR-2 and VEGFR-1 (Carmeliet 2005; Ferrara and Kerbel 2005), while VEGF-C is required for lymphangiogenesis and angiogenesis via VEGFR-3, which is expressed in lymphatic endothelial cells and angiogenic tip cells (Galland et al. 1993; Tammela et al. 2008). VEGF-A and VEGF-C are also expressed by neurons and astrocytes, where they show pleiotropic effects on neural cells. We and others (Acker et al. 2001; Jin et al. 2002; Ogunshola et al. 2002; Schanzer et al. 2004; Le Bras et al. 2006; Li et al. 2006) have reported that they stimulate neural cell survival, enhance the number of neural progenitors, control neuroblast migration during embryonic development (Sondell et al. 2000; Louissaint et al. 2002; Zhang et al. 2003; Wada et al. 2006; Wittko et al. 2009), and represent potential therapeutic tools for neural tissue repair and neurodegenerative diseases (Ferrara et al. 2003; Storkebaum et al. 2004; Ruiz de Almodovar et al. 2009). However, their cellular and molecular targets in the brain have yet to be clarified, especially during SVZ neurogenesis. For example, the targeted deletions of genes encoding VEGF-A and its specific receptor, VEGFR-2, in neural cells have not produced severe neural phenotypes (Haigh et al. 2003; Ruiz de Almodovar et al. 2009; Licht et al. 2010), which suggests that the VEGF-A effects could be indirect and mediated by angiogenic endothelial cells releasing neural growth factors. Here, we analyze the cellular function of VEGF-C and VEGFR-3 in the adult mouse SVZ, where expression of both molecules has been reported recently (Shin et al. 2010). We show that VEGFR-3 is expressed by subventricular NSCs, and that VEGF-C stimulates mitosis of VEGFR-3-expressing NSCs isolated from the adult SVZ. We also demonstrate that, in vivo, VEGF-C promotes subventricular neurogenesis, but not angiogenesis. Finally, we use blocking antibodies (Abs) and two different genetic models of conditional Vegfr3 deletion in neural cells to show that VEGFR-3 function in subventricular astrocytes is critical for adult neurogenesis. These results identify the VEGF-C/ VEGFR-3 system as a novel target to manipulate NSCs and promote adult neurogenesis.

\section{Results}

Vegfr3::YFP reporter mice mirror VEGFR-3 expression

Expression studies using anti-VEGFR-3 Abs have revealed the presence of VEGFR-3 in ventricular progenitors of the embryonic brain (Le Bras et al. 2006). To facilitate visualization and isolate brain VEGFR-3expressing cells, we generated a BAC Vegfr 3 ::YFP transgenic line expressing the YFP reporter under the control of Vegfr3 regulatory sequences (Supplemental Fig. 1A). In postnatal mice, the reporter labeled VEGFR-3-expressing retinal endothelial tip cells (Tammela et al. 2008) as well as Prox-1 and Podoplanin-positive lymphatic endothelial cells, but not arteries and veins (Supplemental Fig. 1B-D). In the adult brain, Vegfr3::YFP labeled some endothelial cells, but not in the SVZ (see below). Vegfr3::YFP ${ }^{+}$neural cells were detected in the SVZ along the striatal wall of the $\mathrm{lv}$ and were double-labeled with an anti-VEGFR-3 Ab (Fig. 1A). Counting of Vegfr $3:: Y F P^{+}$cells labeled by antiVEGFR-3 $\mathrm{Ab}$ on adult forebrain sections indicated that they correspond to $\sim 90 \%$ of Vegfr $3:: Y_{F P^{+}}$cells in the SVZ and brain parenchyma (Supplemental Fig. 2A). Once isolated by FACS, YFP-positive cells showed selective expression of Vegfr3 transcripts (Supplemental Fig. 2B). We conclude that the YFP reporter is a reliable mirror of VEGFR-3 expression in the vascular system and SVZ.

\section{VEGFR-3 expression by NSCs}

To characterize the VEGFR-3-expressing cells in the SVZ, Vegfr3::YFP adult brains sections were stained with specific cell markers, including GFAP, EGFR, Mash1/ Ascll (expressed predominantly by TAPs, but also in a subset of NSCs) (Pastrana et al. 2009), DCX, and $\mathrm{S} 100 \beta$ (for ependymal cells). $\mathrm{YFP}^{+}$cells were predominantly GFAP ${ }^{+}$SVZ astrocytes (Fig. 1B). They included a subpopulation of EGFR-expressing cells (Fig. 1C) and the majority of BrdU label-retaining cells (LRCs); i.e., slowly cycling NSCs (Fig. 1D). In contrast, Mash1/Ascl1 was hardly, if at all, detectable in $\mathrm{YFP}^{+}$cells, suggesting that VEGFR-3 expression is lowered and progressively lost in the majority of TAPs (Supplemental Fig. 2C). A few $\mathrm{DCX}^{+} \mathrm{YFP}^{+}$cells were clustered in the striatal wall (data not shown), but the majority of $\mathrm{DCX}^{+}$neuroblasts were YFP-negative (Fig. 1E). Only a minor population of $S 100 \beta^{+}$ependymal cells expressed YFP (Supplemental Fig. 2D).

The different subpopulations of YFP cells were quantified on three-dimensional (3D) images of the SVZ and by FACS analysis of periventricular cells with similar results (Supplemental Figs. 2E,F, 3). YFP $^{+}$cells represented $\sim 30 \%$ of SVZ cells. Flow cytometry showed that they were enriched in astrocytes, with $60 \%$ of them expressing GFAP. Importantly, YFP ${ }^{+}$cells included $40 \%$ of the total population of EGFR ${ }^{+}$SVZ cells and $87 \%$ of LRCs; i.e., slowly cycling NSCs. In contrast, Mash1/Ascl1 was detected in only $2.8 \%$ of $\mathrm{YFP}^{+}$cells (Supplemental Fig. 3 ), suggesting that VEGFR-3 expression is not maintained in the majority of TAPs. Around 10\% of DCX-expressing cells were $\mathrm{YFP}^{+}$(Supplemental Figs. 2E,F, 3). 


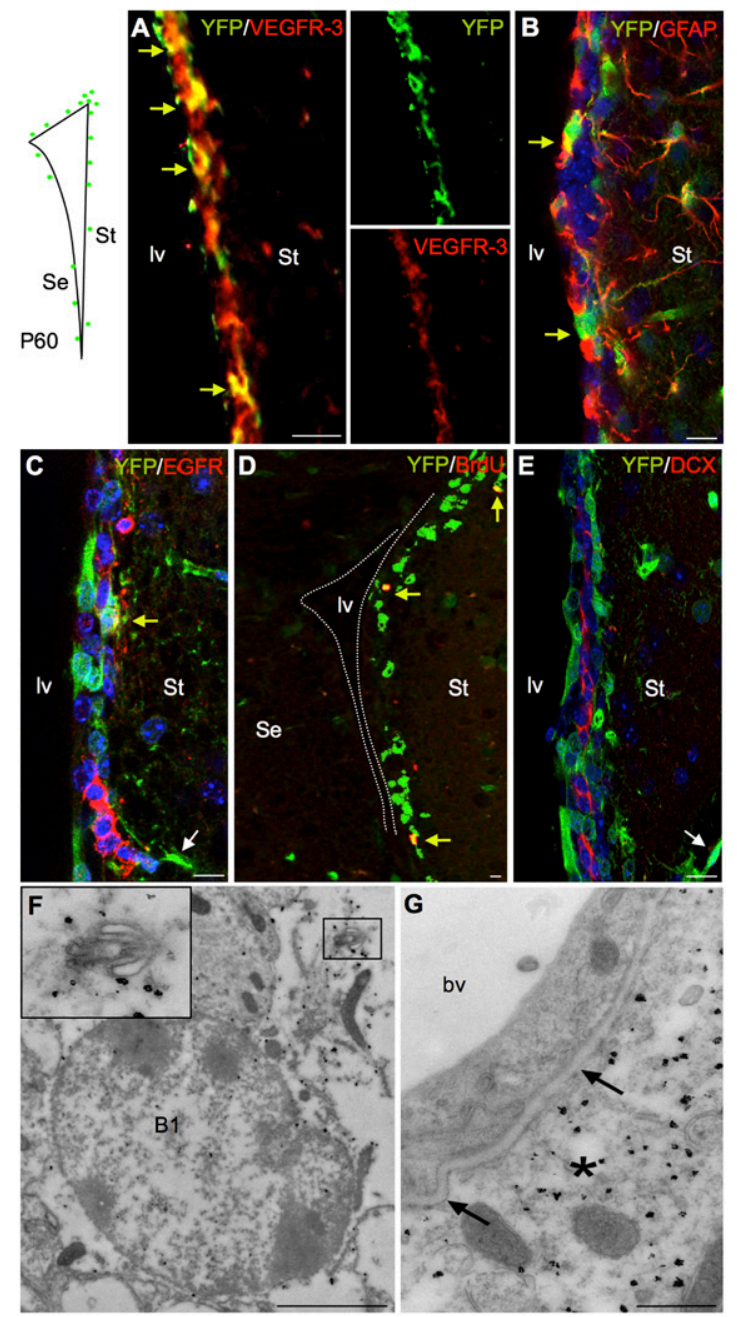

Figure 1. Vegfr3::YFP expression in the adult SVZ. (Top left panel) The localization of Vegfr3::YFP cells (green) around the lv is schematically represented. All images are taken in the lateral ventricular wall facing the striatum $(\mathrm{St})$. Confocal $(A-E)$ and electron microscopy $(F, G)$ images from Vegfr $3:: Y F P$ mouse brain vibratome sections are stained with Abs against cell typespecific markers as indicated. (A) Vegfr3::YFP cells are immunolabeled by anti-VEGFR-3 $\mathrm{Ab}$ (yellow arrows), indicating that YFP faithfully reports VEGFR-3 expression in SVZ cells. (B) Vegfr $3:: Y F P$ cells are a subpopulation of $\mathrm{GFAP}^{+}$cells (yellow arrows), extending long cytoplasmic processes into the SVZ. $(C)$ Few Vegfr3::YFP cells are labeled by anti-EGFR Ab (yellow arrow), but most of the $\mathrm{EGFR}^{+}$cells are YFP-negative. YFP is expressed by few vessels in the striatum outside the SVZ (white arrow). (D) The majority of BrdU LRCs along the striatal SVZ are Vegfr $3:: Y F P$ cells (yellow arrows). (E) Vegfr3::YFP does not label $\mathrm{DCX}^{+}$neuroblasts (red). (White arrow) Blood vessel. $(F, G)$ Immunogold labeling of Vegfr3::YFP cells in the ventricular zone-SVZ. (F) A labeled type B1 NSC extending a primary cilium (magnification in inset). (G) A blood vessel (bv, YFP-negative) is enwrapped by the cytoplasmic process of a Vegfr $3:: Y F P$ astrocyte (asterisk). (Arrows) Basal laminae. Bars: $A-E, 10 \mu \mathrm{m} ; F, 2 \mu \mathrm{m} ; G, 500 \mathrm{~nm}$.

VEGFR-3 expression in SVZ cells was next visualized in the electron microscope after immunogold labeling of Vegfr3::YFP sections with anti-GFP Abs. Immunogold particles were localized almost exclusively in the type B niche astrocytes and the type B1 NSCs that extended a primary cilium into the $\mathrm{lv}$, as well as in a few ependymal cells (Fig. 1F). Endothelial cells of the SVZ did not express YFP, but were surrounded by the cytoplasmic processes of YFP $^{+}$type B cells (Fig. 1G). Immunogold particles were barely seen in neuroblasts and were not detected in TAPs, these two cell types being characterized by an electrodense nucleus with several nucleoli, and cytoplasm with ribosomes and microtubules (Supplemental Fig. 4A,B).

Taken together, these results provide evidence that VEGFR-3 expression in the lv walls is restricted mainly to astrocytes, especially cells that exhibit all phenotypical features of NSCs, including long-term BrdU label retention, the presence of a primary cilium, and expression of EGFR and active morphogen signaling pathways.

\section{VEGF-C expression in the SVZ}

To test whether the presence of VEGFR- $3^{+}$SVZ NSCs correlated with the expression of its ligand, VEGF-C, we compared Vegfc and Vegfr3 expression in compound Vegfc ${ }^{\text {lacZ/+ }}$, Vegfr3::YFP mice. Numerous $\mathrm{X}-\mathrm{Gal}^{+}$cells were adjacent to $\mathrm{YFP}^{+}$cells, and some cells were apparently double-labeled in the SVZ (Supplemental Fig. 5A). $\mathrm{X}$-gal staining was also partially colocalized with GFAP immunolabeling (Supplemental Fig. 5B), suggesting that $V e g f c$ is expressed by astroglial cells, but also by other SVZ cell types. Real-time PCR and ELISA tests performed on extracts of periventricular zone confirmed that both Vegfc transcripts and protein were synthesized in the $\mathrm{lv}$ walls (Supplemental Fig. 5C,D). In the adult, the periventricular expression of $V e g f c$ was increased compared with the neonate, and was detected in both populations of Vegfr3-expressing cells and neighboring Vegfr3-negative cells after FACS sorting from Vegfr3::YFP mice (Supplemental Fig. 5C). These data support a model in which autocrine or paracrine production of VEGF-C might stimulate neural SVZ cells expressing VEGFR-3.

\section{Subventricular VEGFR-3 cells behave as NSCs in vitro}

To assess whether SVZ VEGFR-3 ${ }^{+}$astroglial cells were endowed with NSC properties, $\mathrm{YFP}^{+}$cells were isolated by FACS from adult Vegfr3::YFP periventricular zones and tested in vitro for their ability to form neurospheres, differentiate into neural cell types, and self-renew (Fig. 2A-E).

In the presence of EGF and bFGF, FACS-sorted YFP cells developed primary neurospheres (Fig. 2A,B) that differentiated into neurons, oligodendrocytes, and astrocytes, indicating that $\mathrm{YFP}^{+}$cells include multipotent progenitor/stem cells (Fig. 2C). While both YFP-negative and YFP-positive periventricular cells were capable of forming primary neurospheres, the long-term self-renewing potential of subventricular cells was restricted to the subpopulation of YFP ${ }^{+}$EGF-labeled cells, which were able to give rise to at least three generations of neurospheres (Fig. 2D). Therefore, $\mathrm{YFP}^{+} \mathrm{EGFR}^{+}$periventricular cells are multipotent, self-renewing neurosphere-forming cells and correspond to the majority of NSCs. 
A

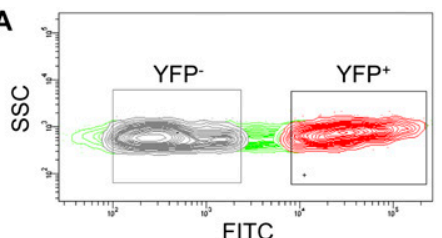

B

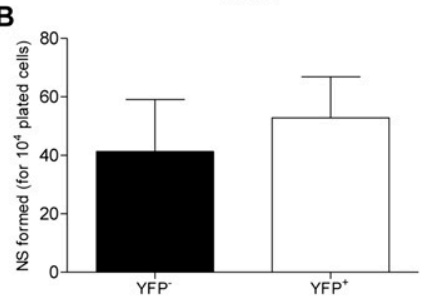

C
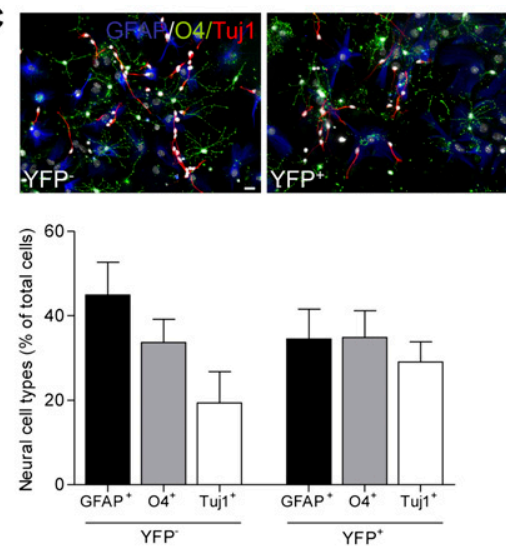

E
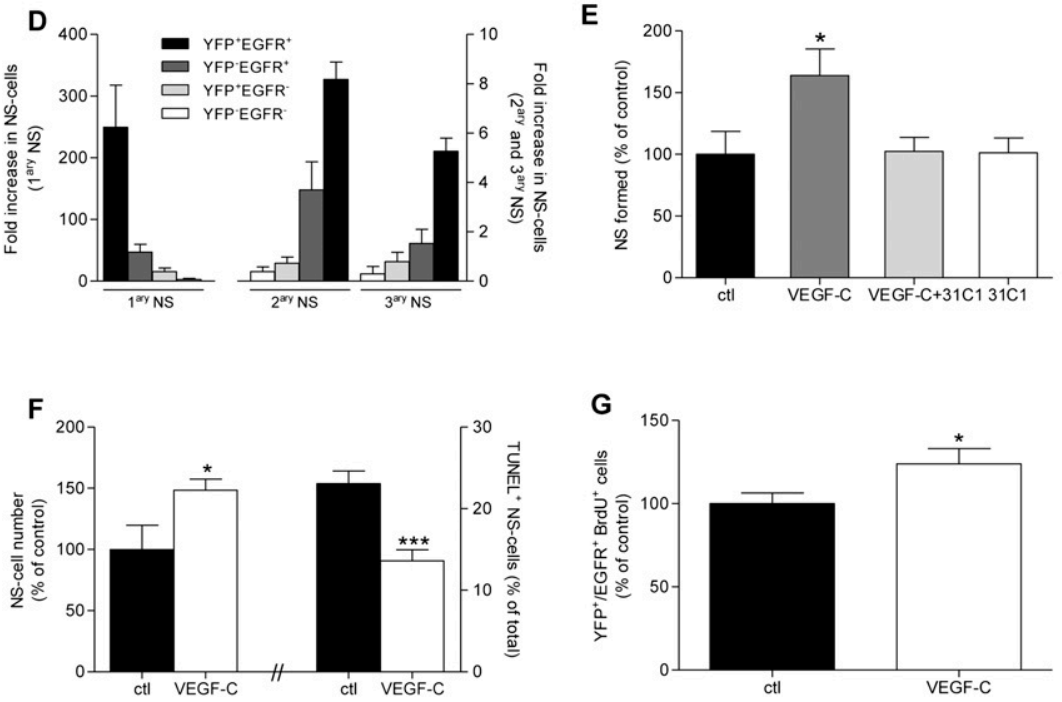

G

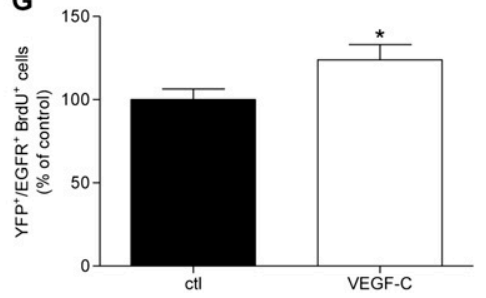

Figure 2. Isolation of NSCs from adult Vegfr3::YFP mice. (A) YFP-positive and YFP-negative cells from the periventricular zone of Vegfr3::YFP mice were FACSsorted. $(B)$ The cells were tested for their ability to generate primary neurospheres in the presence of $\mathrm{bFGF} / \mathrm{EGF}\left(2 \times 10^{4}\right.$ cells per well in 24-well plates). Histograms show that YFP-positive and YFP-negative cells form primary neurospheres and include a subset of $0.5 \%$ of cell-forming spheres $(n=6)$. (C) YFP-positive and YFPnegative cells from primary neurospheres are multipotent, differentiating into $\mathrm{TuJ} 1^{+}$ neurons, $\mathrm{GFAP}^{+}$astrocytes, and $\mathrm{O}^{+}$oligodendrocytes after growth factor removal. Quantification is shown in the histogram (n $=3$ ). (D) $\mathrm{YFP}^{+} / \mathrm{EGFR}^{+}, \mathrm{YFP}^{+} / \mathrm{EGFR}^{-}$, $\mathrm{YFP}^{-} / \mathrm{EGFR}^{+}$, and $\mathrm{YFP}^{-} / \mathrm{EGFR}^{-}$subpopulations isolated after labeling with EGF-647 are tested for their capacity to self-renew and generate secondary ( $2^{\text {ary }}$ NS) and tertiary ( $3^{\text {ary }}$ NS) neurospheres. Histogram shows the increase in the number of neurosphere cells (NS-cells) relative to the number of plated cells. Only EGFR ${ }^{+} /$VEGFR $-3^{+}$ cells generate numerous secondary neurospheres $\left(2^{\text {ary }} \mathrm{NS}\right)$ and tertiary neurospheres ( $\left.3^{\text {ary }} \mathrm{NS}\right)(n=4)$, even forming neurospheres after six passages ( $6^{\text {ary }} \mathrm{NS}$ ) (data not shown), and thus correspond to the majority of NSCs. $(E)$ Primary neurospheres cultured in the presence of VEGF-C $(50 \mathrm{ng} / \mathrm{mL})$ and 31-C1 (a mouse VEGFR-3 function-blocking $\mathrm{Ab}, 5 \mu \mathrm{g} / \mathrm{mL}$ ). The number of neurosphere formed (NS formed) is expressed as a percentage of the control. The 31-C1 Ab blocks the VEGF-C-induced amplification of neurospheres $(n=3) .(F)$ Dissociated neurosphere cells are counted and TUNEL-labeled in control or VEGF-C-containing $(50 \mathrm{ng} / \mathrm{mL})$ medium $(n=3)$. $(G)$ Increased proliferation of $\mathrm{YFP}^{+} / \mathrm{EGFR}^{+}$NSCs following VEGF-C treatment $(50 \mathrm{ng} / \mathrm{mL})$. Cells were pulsed with BrdU $(10 \mu \mathrm{M})$ for $24 \mathrm{~h}$ and fixed after $2 \mathrm{~d}$ in vitro $(n=3)$. Bar: $C, 20 \mu \mathrm{m}$. Error bars indicate SEM. $\left(^{\star}\right) P<0.05 ;\left(^{\star \star \star}\right) P<0.001$, Student's $t$-test.

In the presence of VEGF-C, $\mathrm{YFP}^{+}$cells gave rise to $\sim 60 \%$ more primary neurospheres (Fig. $2 \mathrm{E}$ ), while the number of neurospheres derived from $\mathrm{YFP}^{-}$cells was unchanged (data not shown). VEGF-C thus acts specifically on VEGFR-3-expressing cells. The effect of VEGF-C was inhibited by the blockade of VEGFR-3 signaling using anti-mouse VEGFR-3 Abs (31-C1), and thus was VEGFR3-dependent (Fig. 2E). Dose response assays indicated that the maximum increase of neurosphere numbers is obtained in the presence of $25-50 \mathrm{ng} / \mathrm{mL}$ VEGF-C (Supplemental Fig. 5E). VEGF-C increased the total number of cells and decreased the number of TUNEL-positive cells in neurospheres, indicating that it promotes cell survival (Fig. 2F).

VEGF-A, the other member of the VEGF family, has been reported to stimulate the growth of neurospheres derived from murine embryonic brain and embronic stem cell-derived primitive NSCs (Wada et al. 2006). We confirmed that, like VEGF-C, VEGF-A increased the number of neurospheres derived from the adult SVZ
(Supplemental Fig. 5F). Blocking anti-VEGFR-2 Abs (DC101) abolished VEGF-A-induced neurosphere formation, but did not affect VEGF-C-stimulated neurosphere formation (Supplemental Fig. 5G), indicating that VEGF-A and VEGF-C signal through distinct VEGF receptors in neurosphere cells.

We next examined if VEGF-C was mitogenic for NSCs. $\mathrm{YFP}^{+} \mathrm{EGFR}^{+}$cells were FACS-sorted from the adult SVZ, grown in culture medium alone or with VEGF-C, and labeled with BrdU. Following VEGF-C treatment, the number of $\mathrm{BrdU}^{+}$NSCs was increased by $30 \%$ compared with control cultures (Fig. 2G). This effect required the presence of EGF in the culture medium and was not observed with VEGF-C alone (data not shown). Therefore, VEGF-C and EGF signaling pathways interact to promote cell cycle activation in NSCs. In contrast, VEGF-A did not activate NSC divisions (Supplemental Fig. $5 \mathrm{H}$ ), indicating that its neurogenic effect (Supplemental Fig. 5F) likely results from action on neuroblasts rather than on NSCs. 
VEGF-C/VEGFR-3 signaling stimulates neurogenesis in vivo

To examine the potential of VEGF-C to stimulate neurogenesis in vivo, we overexpressed VEGF-C in the adult SVZ by unilateral injection of adeno-associated viruses (AAVs) encoding VEGF-C (AAV-VEGF-C) in the striatum (Fig. 3A). AAV-HSA and AAV-EGFP were used as negative controls (AAV-ctl). At the time of AAV treatment, all animals were injected intraperitoneally with BrdU to detect cells entering the cell cycle, which were counted $2 \mathrm{~d}$ following AAV injection. Immunolabeling with an anti-VEGF-C Ab in the vicinity of the AAV injection site confirmed ectopic VEGF-C expression, and ELISA on forebrain extracts indicated a peak of twofold increase of VEGF-C expression at day 2 post-infection in AAVVEGF-C-infected brains (Supplemental Fig. 6A,B). This overexpression is transient and has almost disappeared 3 wk after AAV infection (data not shown). Compared with controls, treatment with AAV-VEGF-C increased the number of $\mathrm{BrdU}^{+}$subventricular cells and decreased the number of Caspase $-3^{+}$cells engaged in programmed cell death (PCD) (Fig. 3B). Staining of neuroblasts with antiDCX Ab showed a threefold increase of the $\mathrm{DCX}^{+}$cell population, and thus of neurogenesis, in the SVZ of AAVVEGF-C-treated mice (Fig. 3C). When AAV-VEGF-C in- jections were given to Vegfr3::YFP mice, more $\mathrm{BrdU}^{+} /$ $\mathrm{YFP}^{+}$cells formed in the SVZ, indicating that VEGF-C promotes cell cycle entry of VEGFR-3-expressing cells (Fig. 3D). Quantification of GFAP and YFP staining showed a significant increase in the SVZ of AAV-VEGFC-infected animals compared with controls (Fig. 3E). Together, these results demonstrate that AAV-VEGF-C stimulates neurogenesis by enhancing SVZ cell survival, activating NSC cell cycle entry, and subsequently increasing neuroblast production.

To exclude the possibility that the neurogenesis promoted by VEGF-C had developed as an indirect consequence of increased angiogenesis, we examined the pattern of $\mathrm{CD} 1^{+}$cerebral endothelial cells following overexpression of AAV-VEGF-C and AAV-VEGF-A overexpression. AAV-VEGF-C-injected brains showed a similar $\mathrm{CD} 31^{+}$endothelial cell pattern as compared with AAV-ctl, although there was an increase in the density of $\mathrm{GFAP}^{+}$subventricular astrocytes (Fig. 4). Similar results were obtained using AAV-VEGF-C156S encoding a variant that cannot bind VEGFR-2 (Joukov et al. 1996). In striking contrast, AAV-VEGF-A induced a dense network of $\mathrm{CD} 31^{+}$endothelial cells at the site of injection, with local hemorrhages that were detected by the presence of TER $119^{+}$red blood cells dispersed in the brain parenchyme (Fig. 4; Supplemental Fig. 6C). Overexpression of
A
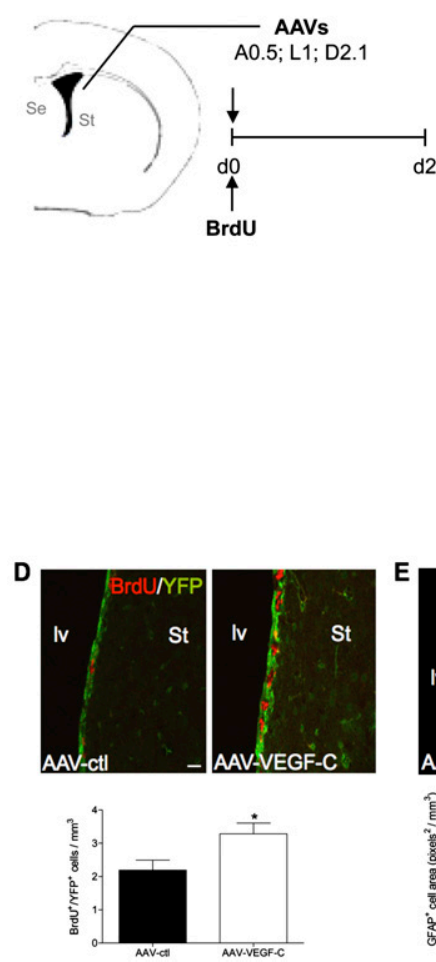
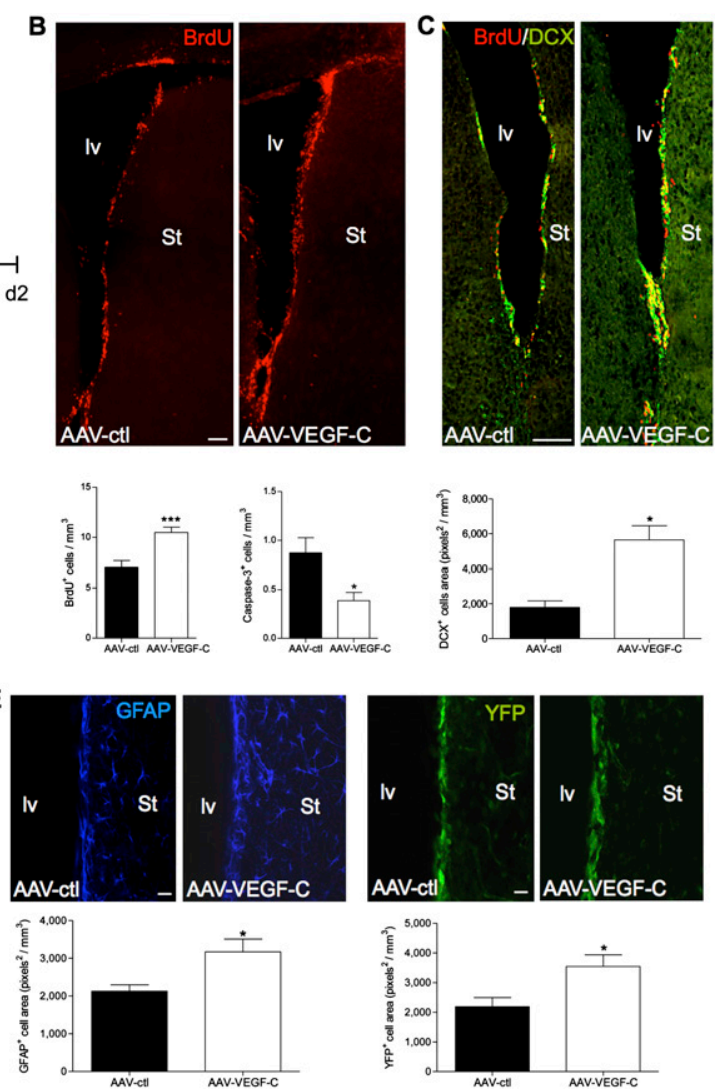

Figure 3. In vivo VEGF-C overexpression. (A) Adult mice are infected with either AAV-VEGF-C or control AAVs (AAV-ctl: AAV-EGFP and AAV-HSA) in the vicinity of the SVZ (coordinates from the bregma: anterior, 0.5 ; lateral, 1.0 ; depth, $2.1 ; n=7$ animals per group) and injected intraperitoneally with BrdU the same day. $(B)$ Coronal brain cryosections from animals sacrificed at day 2 post-infection are analyzed for the number of BrdU cells (red) in the SVZ. Both the dorsolateral and ventral regions along the striatal wall show more BrdU $^{+}$cells in AAV-VEGF-C-treated animals as compared with AAV-ctl. Histograms indicate the number of newborn $\mathrm{BrdU}^{+}$cells (bottom left) and activated Caspase- $3^{+}$cells (bottom right) in the SVZ. AAV-VEGF-C promotes the production of newborn cells and inhibits PCD in SVZ cells. $(C)$ Coronal cryosections of the periventricular zone immunolabeled with anti-DCX Ab (green). In the striatal SVZ, DCX labeling reflects neuroblast production. AAV-VEGF-C induces a significant expansion of DCX expression in the SVZ compared with controls. $(D, E)$ Coronal brain vibratome sections from Vegfr $3:: Y F P$ adult mice infected with either AAVVEGF-C or AAV-ctl and sacrificed at day 2. Dividing VEGFR-3-expressing cells $\left(\mathrm{BrdU}^{+} \mathrm{YFP}^{+}\right)$are increased in AAV-VEGFC-treated animals $(D)$, while the subventricular expressions of GFAP and YFP are also enhanced (E), as compared with controls.(St) Striatum. Bars: $B, C, 100 \mu \mathrm{m} ; D, E, 20 \mu \mathrm{m}$. Error bars indicate SEM. $\left(^{\star \star \star}\right) P<0.001$, Student's $t$-test. 


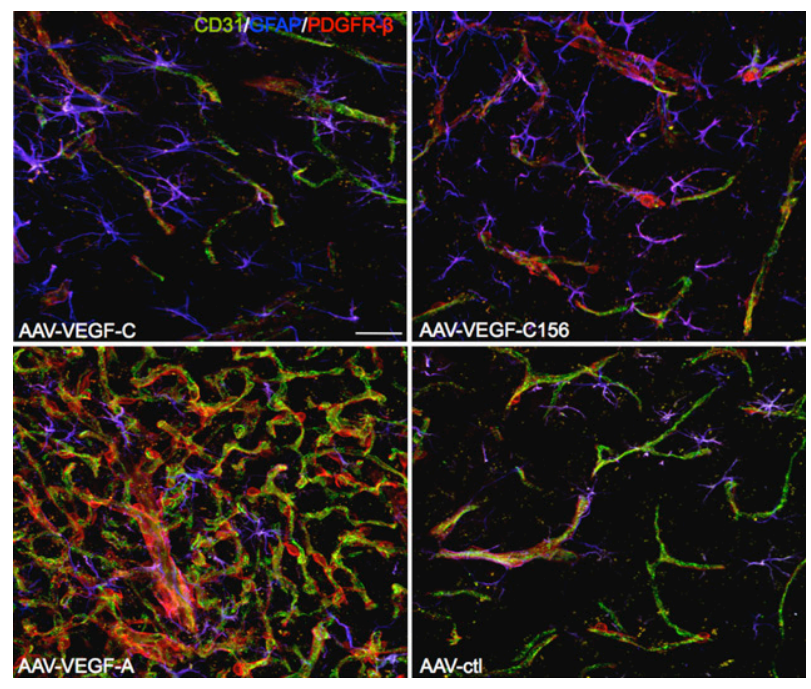

Figure 4. Effects of AAV-VEGF-A and AAV-VEGF-C overexpression on the adult SVZ. Blood vessel pattern in the striatal wall, as shown by labeling of endothelial cells (CD31, green) and pericytes (PDGFR- $\beta$, red), while astrocytes are stained with antiGFAP Ab (blue). AAV-VEGF-C-treated and AAV-VEGF-C156treated (a VEGF-C variant that cannot bind to VEGFR-2) animals display a vascular network similar to AAV-ctl. In contrast, AAV-VEGF-A induced robust angiogenesis, which is attested to by a dense network of $\mathrm{CD} 31^{+}$endothelial cells and PDGFR $\beta^{+}$pericytes at the site of injection. Note that the number of astroglial cells increased in AAV-VEGF-C- and AAV-VEGF-C156-treated animals compared with controls. Bar, $20 \mu \mathrm{m}$.

VEGF-A is thus strongly angiogenic and might promote SVZ neurogenesis indirectly by providing increased trophic supplies from endothelial cells to NSCs. In contrast, VEGF-C-induced neurogenesis was not associated with increased angiogenesis. Taken together, these data support a model in which VEGF-C triggers SVZ neurogenesis by directly stimulating VEGFR $-3^{+}$subventricular astrocytes and NSCs independently of angiogenesis.

We next tested whether the activation of VEGF-C/ VEGFR-3 signaling in the SVZ would result in an increase of newly formed neurons in the OB. SVZ-derived neurons have been reported to selectively migrate to the $\mathrm{OB}$, whose cell layers are colonized within $3 \mathrm{wk}$ (Nissant et al. 2009). Examination of the forebrain by immunolabeling with anti-BrdU and anti-DCX Abs at day 21 after AAV infection showed that AAV-VEGF-C-treated animals displayed $\mathrm{BrdU}^{+}$cells only in the SVZ, rostral migratory stream (RMS), and OB, with more abundant BrdU-expressing cells in the OB compared with controls, especially in the granular layer (Supplemental Fig. 6D). BrdU-positive cells were mainly DCX- and Neu-N-positive cells (Supplemental Fig. 6D). In contrast to AAV-VEGF-C, infections with AAV-VEGF-A did not increase OB neurogenesis after $3 \mathrm{wk}$ (Supplemental Fig. 6E), although an early and transient activation of subventricular cell proliferation and expansion of $\mathrm{DCX}^{+}$neuroblasts was observed after $2 \mathrm{~d}$, which is likely secondary to the increase of angiogenesis (Supplemental Fig. 6F-H). Taken together, these studies provide evidence that, among VEGF family members, VEGF-C potently stimulates $\mathrm{OB}$ neurogenesis in the adult.

\section{SVZ neurogenesis is VEGFR-3-dependent}

To examine the effects of VEGFR-3 inhibition on SVZ neurogenesis, we developed a genetic approach to specifically delete Vegfr3 in all neural cell types. Vegfr3 ${ }^{\text {lox/lox }}$ mice were intercrossed with Brn4::Cre mice that expressed Cre recombinase in embryonic and adult neural stem/precursor cells as well as in post-mitotic CNS neurons. Brn4 encodes a POU domain transcription factor expressed by neuroepithelial cells from embryonic day 8.5 (E8.5) and is involved in the development of neurons (Heydemann et al. 2001). The Brn4::Cre mouse has already been used to generate conditional loss of function of b-catenin in the CNS (Zechner et al. 2003). Cre expression in the adult forebrain was restricted to the lv walls and scattered parenchymal cells, but was excluded from CD $31^{+}$endothelial cells (Supplemental Fig. 7A). Brn $4:: C r e$, Vegfr3 $3^{\text {lox/lox }}$ mice were viable but lacked VEGFR-3 expression in the SVZ (Supplemental Fig. 7B). In contrast, they expressed VEGFR-3 in their lymphatic vessels and displayed a normal pattern of LYVE-1-positive lymphatics and CD31-positive blood vessels in the heart and skin (Supplemental Fig. 7C). Brn4::Cre, Vegfr $3^{\text {lox } / l o x}$ mice thus exhibit selective deletion of Vegfr3 in neural cells without affecting the vasculature.

We analyzed the neurogenic activity of Brn $4::$ Cre, Vegfr3 ${ }^{\text {lox/lox }}$ neonates (postnatal day 15 [P15]) by quantifying BrdU ${ }^{+}$cells in the $\mathrm{lv}$ walls and the $\mathrm{OB}$ at $1 \mathrm{wk}$ after intraperitoneal injection of BrdU. In Brn $4:$ Cre, Vegfr $3^{\text {lox/lox }}$ mice, the SVZ showed significantly fewer BrdU ${ }^{+}$cells than in Vegfr $3^{\text {lox/+ }}$ controls ( $n=4$ per group) (Fig. 5A). In the OB, the number of $\mathrm{BrdU}^{+}$cells per $\mathrm{OB}$ area was also reduced (Fig. 5B). The OB was significantly reduced in size (volume in pixel ${ }^{3}$, mean \pm SEM: Vegfr3 ${ }^{\text {lox } /+}=465 \pm 24, n=5$; Vegfr $\left.3^{\text {lox/lox }}=226 \pm 19, n=6 ; p \leq 0.0001\right)$ and showed a disorganization of the neuronal layers with a loss of $\mathrm{NeuN}^{+}$ neurons (Fig. 5C). In contrast, the surface area of the CD31 $1^{+}$ vascular network in the OB was similar between genotypes (Fig. 5D), which confirmed that the development and maintenance of brain vasculature is unaffected by Brn4::Cre-mediated Vegfr3 deletion in neural cells. The loss of Vegfr3 in neural cells therefore specifically and severely impairs neonatal neurogenesis in the $\mathrm{lv}$ and interneuron maintenance in the $\mathrm{OB}$ without affecting angiogenesis.

Examination of the SVZ in adult Brn 4::Cre, Vegfr3 ${ }^{\text {lox } / l o x}$ mice by cresyl-violet staining showed that the SVZ had a strongly reduced cell density compared with Brn $4::$ Cre, Vegfr $3^{\text {lox/+ }}$ controls (Fig. 5E,F). The extension of the GFAPpositive astroglial network in the SVZ was also reduced (Fig. 5G). The OB remained smaller in size compared with Brn4::Cre, Vegfr3 ${ }^{\text {lox/+ }}$ littermates (volume in pixel $^{3}$, mean \pm SEM: Vegfr $3^{\text {lox } /+}=3033 \pm 294, n=6 ;$ Vegfr $^{\text {lox } / \text { lox }}=$ $1413 \pm 117, n=5 ; p \leq 0.001)$, indicating the persistence of reduced neurogenic activity in adult Brn $4:: C r e$, Vegfr $3^{\text {lox } / l o x}$ mice (Fig. 5H).

To exclude that the SVZ and OB phenotype seen in Brn4::Cre, Vegfr3 ${ }^{\text {lox/lox }}$ mice was indirect and not, for 

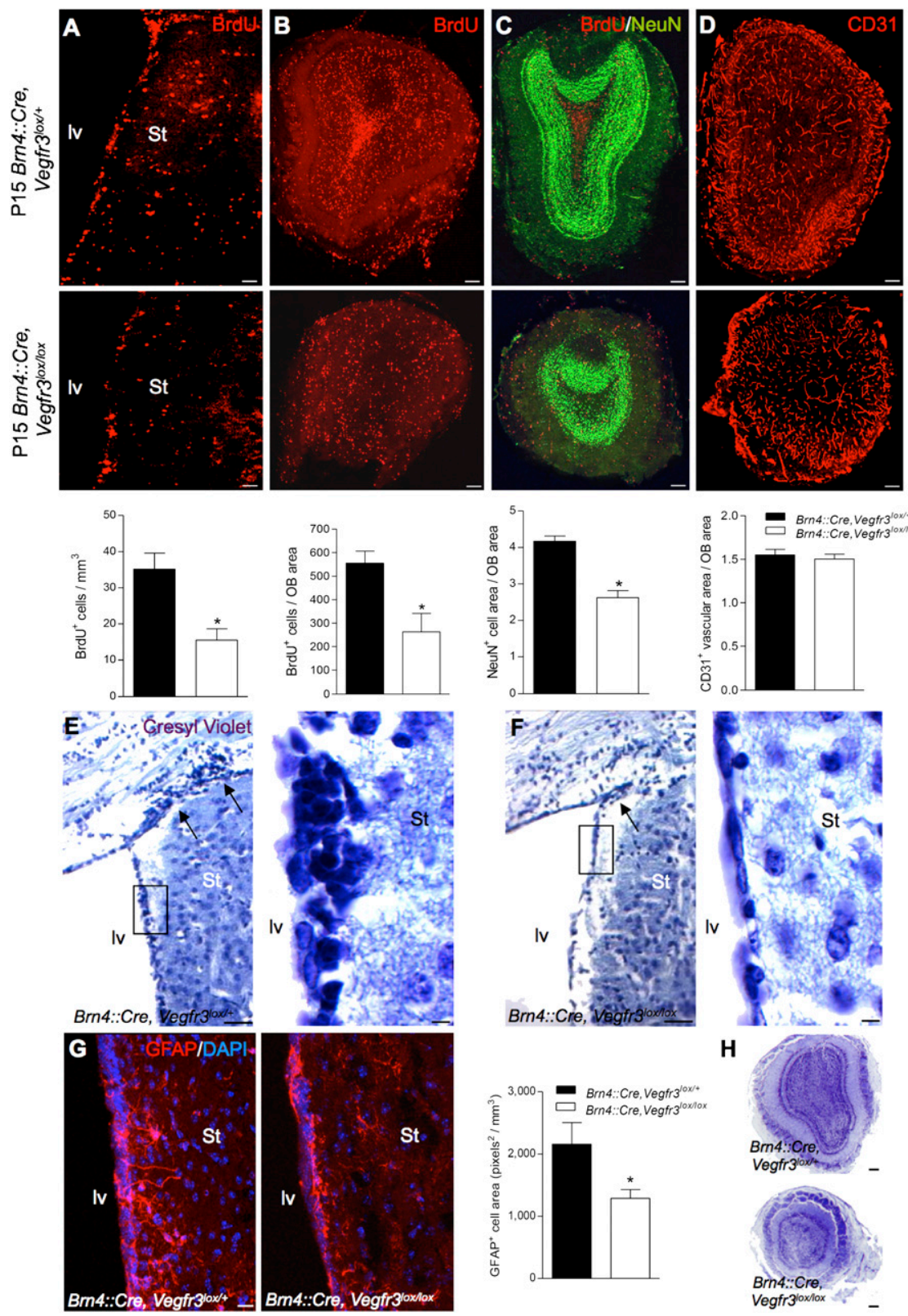

Figure 5. Genetic and pharmacological loss of VEGFR-3 function in vivo. $(A-D)$ Neonatal neurogenesis in P15 Brn4::Cre, Vegfr $3^{\text {lox/lox }}$ mice. Brn4::Cre, Vegfr $3^{\text {lox/lox }}$ mice show a decreased number of $\mathrm{BrdU}^{+}$ cells in the $\operatorname{lv}(A)$ and $\mathrm{OB}(B)$, as compared with Brn4::Cre, Vegfr3 $3^{\text {lox } /+}$ controls. $(C)$ The $\mathrm{OB}$ is reduced in size and is disorganized, with a reduction of $\mathrm{NeuN}^{+}$cells. $(D)$ No decrease of the density of CD31 labeling was observed. $(E-G)$ SVZ of adult mice with a conditional deletion of Vegfr3 in neural cells (Brn4::Cre, Vegfr $3^{\text {lox } / l o x}$ homozygotes; control Brn $4:: C r e$, Vegfr $3^{\text {lox/+ }}$ heterozygotes). (E,F) Cresyl-violet staining of brain coronal paraffin sections from control $(E)$ and Vegfr3-deficient $(F)$ mice. The SVZ cell density along the striatal wall and in the lateral horn is reduced in Vegfr $3^{\text {lox/lox }}$ homozygotes compared with controls. Insets show magnifications of boxed areas in $E$ and $F$. $(G)$ Anti-GFAP staining indicates that the SVZ astroglial network is thinner and disorganized in Vegfr $3^{\text {lox/lox }}$ homozygotes compared with controls. $(H)$ Cresylviolet staining of $\mathrm{OB}$ coronal paraffin sections shows the reduction in $\mathrm{OB}$ size of Vegfr3-deficient mice compared with heterozygote control. Bars: $A, 50 \mu \mathrm{m} ; B-F, H$, $100 \mu \mathrm{m} ; G, 20 \mu \mathrm{m}$; insets in $E, F, 5 \mu \mathrm{m}$. Error bars indicate SEM. $\left({ }^{*}\right) P<0.05$, Student's $t$-test. example, due to the deletion of Vegfr3 in developing neural cell populations before birth, we developed a second function-blocking approach using a mouse VEGFR-3blocking Ab (rat IgG2a 31-C1 Ab) (Bock et al. 2008) that efficiently blocked VEGF-C-induced neurosphere growth (Fig. 2E). We delivered function-blocking VEGFR-3 Abs with an Alzet miniosmotic pump for $6 \mathrm{~d}$ into the cerebral parenchyme above the lv of adult Vegfr3::YFP mice. Control animals were infused with rat IgG2a during the same period. Animals were injected with BrdU to enable detection of cells entering the cell cycle. Anti-VEGFR-3treated animals exhibited a severe reduction of subventricular BrdU-positive cells $(80 \%)$ and a twofold decrease of the SVZ area expressing YFP and GFAP (Fig. 6A). Ab treatment thus mirrors SVZ defects seen in Brn $4::$ Cre, Vegfr $3^{\text {lox/lox }}$ mice (i.e., a reduction of the VEGFR-3- expressing astroglial network and neurogenesis), which demonstrates that the blocking of VEGF-C binding to VEGFR-3 on astrocytes inhibits adult subventricular neurogenesis.

To unambiguously determine if VEGFR-3 is required by subventricular astrocytes in adult neurogenesis, Vegfr3 deletion was induced in Glast-expressing astrocytes and NSCs of the SVZ using a Glast::CreERT2 driver line (Mori et al. 2006). Glast::CreERT2 mice express the inducible form of Cre (CreERT2) in the locus of the astrocyte-specific glutamate transporter (GLAST), allowing precisely timed gene deletion in adult astrocytes following tamoxifen $(\mathrm{Tx})$ injection. A 5-d treatment of adult Glast::CreERT2, Vegfr $3^{\text {lox/lox }}$ mice with Tx allowed the robust activatation Cre expression in SVZ astrocytes and efficiently reduced Vegfr3 expression $\mid n=3$ animals 

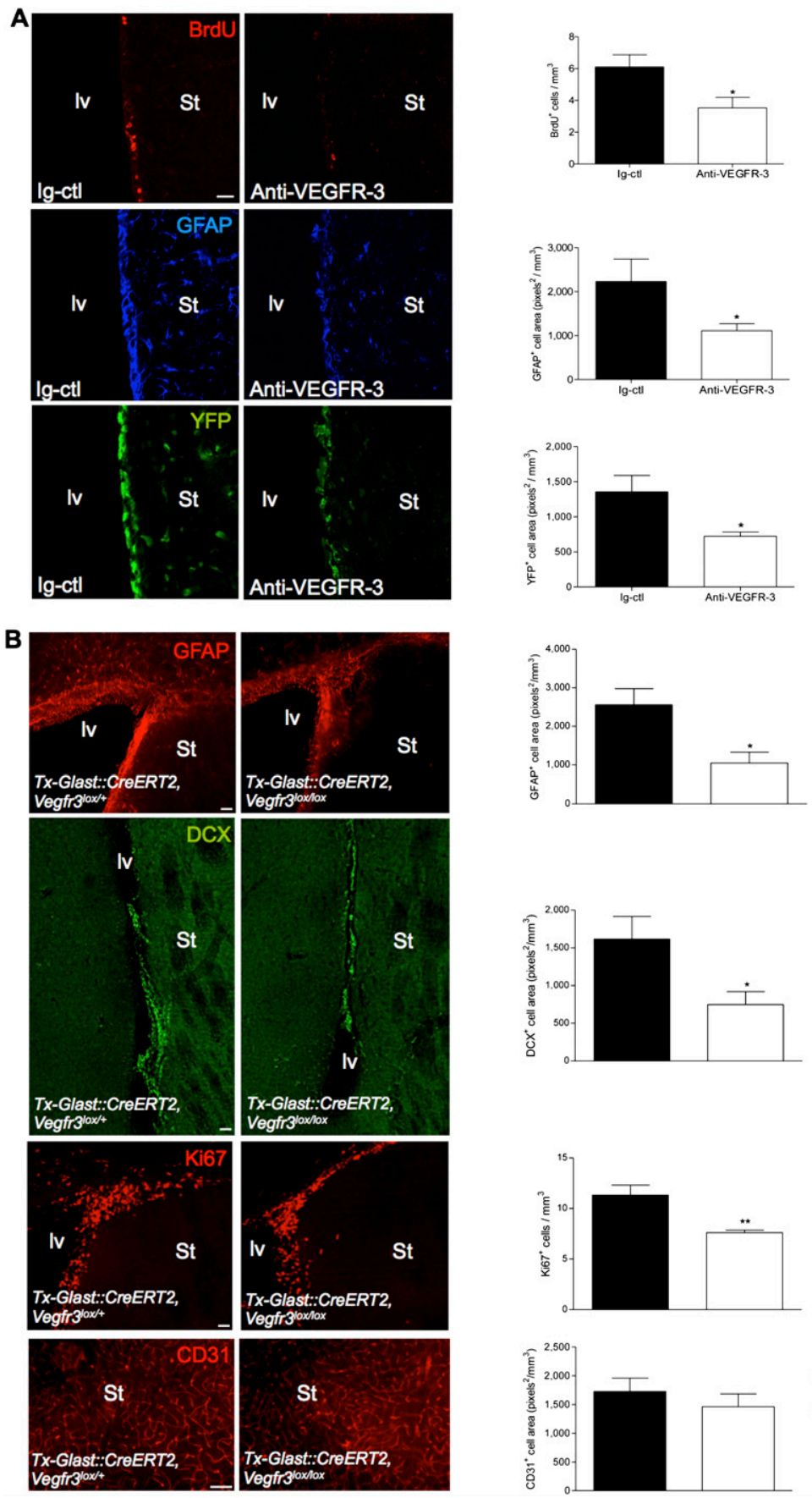

Figure 6. $(A)$ Function-blocking Abs against VEGFR-3 (31-C1: anti-VEGFR-3) or rat IgG2a (Ig-ctl, control) were delivered above the lv of adult Vegfr3::YFP mice with an Alzet miniosmotic pump for $6 \mathrm{~d}$ (coordinates from the bregma: anterior, 0.5; lateral, 1.0; depth, 0). Coronal brain vibratome sections are stained with specific markers as indicated (left panels), and histograms show the corresponding cell quantifications (right panels). Anti-VEGFR-3treated mice display few $\mathrm{BrdU}^{+}$cells and reduced expression patterns for GFAP and YFP in the SVZ, as compared with control animals. (B) Tx-induced deletion of Vegfr3 in subventricular astroglial cells in GlastCreERT2::Cre, Vegfr3 ${ }^{\text {lox } / l o x}$ mice. Coronal cryosection of the adult lv walls showing reduction in the expression of GFAP and DCX, and in the number of dividing $\mathrm{KI}_{6} 7^{+}$cells. No changes were observed in the pattern of $\mathrm{CD} 31^{+}$endothelial cells. Quantifications confirm a phenotype similar to the one observed in Brn4::Cre, Vegfr $3^{\text {lox } / l o x}$ mice. Bars: $A, 20 \mu \mathrm{m} ; B, 50 \mu \mathrm{m}$. $n=3-4$ animals per group. Error bars indicate SEM. $\left(^{*}\right) P<0.05 ;\left(^{\star \star}\right) P \leq 0.005$, Student's $t$-test. per group) (Supplemental Fig. 8D,E). One week after the last Tx treatment, Glast::CreERT2, Vegfr3 $3^{\text {lox/lox }}$ mice developed a subventricular phenotype similar to the one observed in animals injected with anti-VEGFR-3 Abs and in Brn $4::$ Cre, Vegfr3 ${ }^{\text {lox } / l o x}$ mice (Fig. 6B). GFAP expression, cell proliferation, and neuroblast expansion were significantly decreased in the SVZ, without detectable anomalies of the endothelial network (Fig. 6B). Therefore, three different approaches blocking VEGFR-3 function in the brain induce the same characteristic reduction of both astrocyte and neuroblast populations in the SVZ, establishing the critical, direct role for VEGFR-3 in subventricular astrocytes and neurogenesis.

\section{Discussion}

We show that VEGFR-3 is a marker for a subpopulation of subventricular astrocytes that includes almost all NSC/ type $\mathrm{B} 1$ astrocytes in the adult mouse brain. NSCs reside in neurovascular niches in the SVZ, and the vasculature has been shown to represent a key component of the NSC niche (Mirzadeh et al. 2008; Shen et al. 2008; Tavazoie 
et al. 2008), suggesting potential molecular cross-talk between NSCs and vessels via VEGF signaling. However, VEGFR-3 labels only subsets of endothelial cells in the adult mouse vasculature-notably lymphatic vessels, which are absent from the brain. In the SVZ, we show that Vegfr3 is not expressed in endothelial cells, but is restricted to neural cells, including NSCs of the neurovascular niche, indicating that its ligand, VEGF-C, could directly activate neurogenesis (Fig. 7). Accordingly, intracerebral overexpression of VEGF-C activates VEGFR$3^{+}$cell cycle entry and activates neurogenesis, but does not increase angiogenesis. Overexpression of the related factor VEGF-A increases both angiogenesis and neurogenesis, confirming previous reports that VEGF-A might stimulate neurogenesis directly or indirectly via release of neurotrophic factors from blood vessels (Licht et al. 2010). As VEGF-C acts directly on neural cells, including NSCs expressing VEGFR-3, treatment with VEGF-C might stimulate neurogenesis in disease situations without causing angiogenesis and vascular permeability that might lead to side effects such as brain edema.

Phenotypic analysis of Vegfr3-expressing SVZ cells showed that they correspond to a majority of type B astrocytes and include most, if not all, cells with the currently known hallmarks of NSCs, including type B1 cells with a primary cilium and long-term BrdU retention. In addition, $\sim 10 \%$ of Vegfr3-expressing cells express EGFR, and sorted VEGFR- $3^{+} / \mathrm{EGFR}^{+}$cells retain selfrenewal and the capacity to generate neurospheres over extended passages in vitro. Thus, EGFR and VEGFR-3 appear to be the best current marker combination for isolation of NSC populations. The Vegfr3::YFP reporter mouse that we generated represents a valuable tool for such experiments, and additionally allows monitoring of the lymphatic vasculature in development and disease. As both VEGFR-3 and EGFR signaling pathways contribute to the control of stem cell survival and activation in the SVZ neurogenic niches, it will be interesting to investigate downstream signaling mechanisms and potential cross-talk between these two receptor systems.

Vegfr3-expressing NSCs correspond to almost all of the subventricular NSCs along the lv walls, suggesting that VEGFR-3 signaling might participate in the postnatal production of various neuronal and glial cell types. Indeed, deletion of Vegfr3 in neural cells using Brn4::Cre, Vegfr $3^{l o x} /{ }^{l o x}$ mice leads to a significant reduction of the Vegfr3-expressing astroglial network and the amount of neurogenic activity in the SVZ, with loss of newborn SVZ cells in juvenile animals and severe cell depletion in the SVZ of the adult. Brn $4::$ Cre, Vegfr $3^{\text {lox } / \text { lox }}$ mice might also display other neurogenesis defects, as VEGFR-3 is expressed by other neural cell populations outside the SVZ (Le Bras et al. 2006). However, short-term blocking of VEGFR-3 function with an anti-VEGFR-3 Ab in the adult brain led to a decrease of VEGFR-3 expression and a disorganization of the subventricular astrocytes, which are associated with a strongly impaired neurogenesis along the $l v$, similar to the phenotype seen in Brn 4::Cre, Vegfr $3^{\text {lox/lox }}$ mice. In addition, Tx induction of Glast::CreERT2, Vegfr3 ${ }^{\text {lox/lox }}$ mice provokes a similar phenotype, supporting a model in which VEGFR-3 function is directly activated in adult SVZ astrocytes to maintain the astroglial niche and NSC activity (Fig. 7).

Our data indicate that, among the different VEGF receptors, VEGFR-3 has an essential neural cell-autonomous effect in the SVZ. To our knowledge, this provides the first clear evidence for the direct function of a VEGFR family member in NSCs. Although additional VEGFRs are expressed in neural cells (Louissaint et al. 2002; Le Bras et al. 2006; Wada et al. 2006; Wittko et al. 2009), our three different function-blocking strategies show that the absence of VEGFR-3 signaling cannot be compensated by VEGFR-1 or VEGFR-2 in vivo. Therefore, while our data are compatible with possible VEGFR-1 or VEGFR-2 actions, or perhaps even VEGFR-1 or VEGFR-2/VEGFR-3 heterodimer function in neural cells of the subventricular

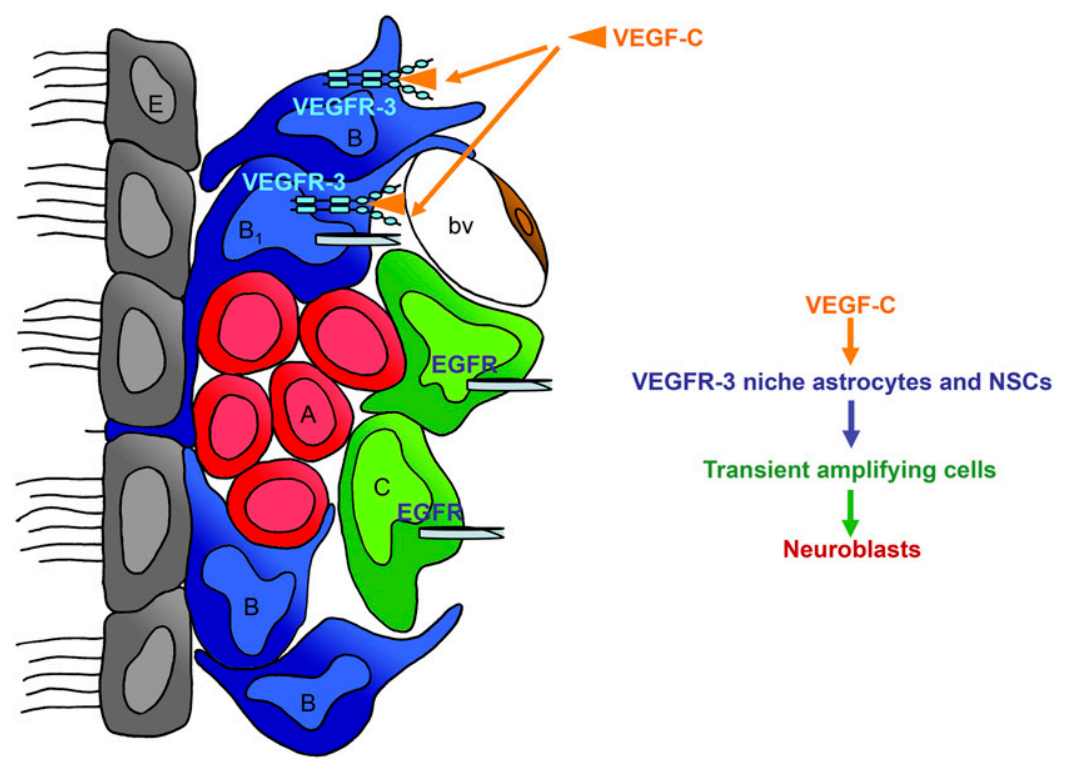

Figure 7. Proposed model for VEGF-C and VEGFR-3 function in the adult SVZ. VEGFR-3 is expressed by a subpopulation of astrocytes (B) and almost all NSCs (B1), but not by the majority of TAPs $(\mathrm{C})$, neuroblasts (A), and endothelial cells (bv). EGFR is expressed by the subpopulation of VEGFR-3 NSCs. VEGF-C produced by SVZ astrocytes and also other cell types promotes activation of VEGFR-3-expressing cells (i.e., niche astrocytes and NSCs), which increase in number following overexpression of VEGF-C. This enhances the number of TAPs and neuroblasts. 
niche, our results clearly establish VEGFR-3 as the functionally predominant family member in NSCs.

VEGFR-3 and VEGF-C are coexpressed along the $1 \mathrm{v}$ walls at all postnatal stages examined. In the dentate gyrus, where neurogenesis also occurs in the adult, expression of both VEGF-C and VEGFR-3 has been reported (Shin et al. 2008), and we observed, on ultrathin hippocampal sections from Vegfr $3::$ YFP mice, that Vegfr3 expression in the dentate gyrus was restricted to astroglial cells (C Alfaro-Cervello, pers. comm.). These observations support a role for VEGF-C and VEGFR-3 in murine adult neurogenesis in both the SVZ and dentate gyrus. Our data show that VEGF-C activates neurogenesis and has survivaland proliferation-promoting effects on SVZ cells. In vitro, VEGF-C increases the number and survival of neurosphere cells via VEGFR-3 signaling. VEGF-C, but not VEGF-A, also promotes BrdU incorporation of $\mathrm{YFP}^{+} \mathrm{EGFR}^{+}$NSCs. In vivo, exogenous VEGF-C and VEGFR-3 loss of function strongly affects proliferation and maintenance, respectively, of subventricular astrocytes. Taken together, these data suggest that VEGF-C/VEGFR-3 signaling promotes survival and maintenance of niche astrocytes as well as the cell cycle progression of NSCs. Mechanistically, proteomic analysis of VEGF-C-treated purified NSCs indicates that VEGFR-3 signaling regulates cell cycle proteins as well as the production of factors promoting neurogenesis, such as BDNF (T Lam and JL Thomas, unpubl.). Functional characterization of these proteins will show if they are downstream targets of VEGFR-3 signaling in NSCs.

To conclude, this study reveals a direct role of VEGFR-3 in murine neurogenesis. VEGF-C and VEGFR-3 act as a neural cell-autonomous signaling system that specifically targets subventricular astroglial cells. The survival effect of VEGF-C and the expression of VEGFR-3 by NSCs are two specific valuable features, opening a potential use of these molecules for stimulating postnatal neurogenesis in humans.

\section{Materials and methods}

\section{Animals}

The Vegfr $3:: Y F P$ construct was generated from a BAC clone (RP23-65D23, Chori BACPAC Resources) containing an 238$\mathrm{kb}$ genomic fragment spanning the mouse Vegfr3 locus. The targeting vector used to modify BAC RP23-65D23 (Supplemental Fig. 1A) was designed to insert the sequence of a brighter variant of YFP, Venus YFP (Nagai et al. 2002), into the first coding exon of the Vegfr3 gene. Homology regions $\sim 0.4 \mathrm{~kb}$ in length were amplified by PCR from the genomic BAC using Expand HighFidelity TaqI DNA Polymerase (Roche). The 5' and 3' homology sequence, the YFP gene, and the fragment including the polyA site and the kanamycin resistance cassette flanked by frt sites were isolated from different vectors, cloned into the shuttle vector pBluePacAsc, and checked by restriction digestion. Two modifications of clone RP23-65D23 were introduced to generate the BAC construct. First, a $\operatorname{lox} P$ site was removed and an ampicillin resistance cassette including an AscI restriction site was inserted using homologous recombination in EL250 bacteria. Second, bacteria carrying modified BAC were transformed with the targeting vector linearized previously by AscI and PacI digestion, and homologous recombination events were picked by positive selection with ampicillin and kanamycin. Subsequently, the FRT-flanked kanamycin resistance cassette was excised using the flpe gene under the control of an arabinose-inducible promoter of the EL250 strain. Modified BAC was tested for the absence of rearrangements using EcoRV restriction analysis and pulsed-field gel electrophoresis. The modified BAC clone was linearized by AscI digestion and separated in low-melting-point agarose gel (NuSieve GTG) using the CHEF-DR II Pulsed-Field Electrophoresis system (Bio-Rad). Linearized BAC DNA was extracted from agarose, purified using $\beta$-agarase enzyme (New England Biolabs), and dialyzed against microinjection buffer, then used for pronuclear injections into fertilized mice oocytes (SEAT). Injections resulted in three independent founder lines carrying the BAC transgene. All of the lines were identified by PCR analysis of genomic DNA using primers for the YFP gene (YFP fwd, 5'-AAGGGCGAGCTGTTCAC-3'; YFP rev, 5'-CTGT TGTAGTTGTACTCCAG-3'), and showed an expression pattern similar to YFP fluorescence in vivo.

Brn4:Cre (Heydemann et al. 2001; Zechner et al. 2003) and Vegfr3 ${ }^{\text {lox/lox }}$ (Haiko et al. 2008) mice were crossed to obtain Brn4::Cre, Vegfr $3^{\text {lox } /+}$ animals and were mated with Vegfr $3^{\text {lox } / \text { lox }}$ mice to generate Brn $4:: C r e$, Vegfr $3^{\text {lox/lox }}$ mice. DNA from the brain, heart, and lung was used for PCR to visualize recombined the Vegfr3 allele using the following primers: fwd, 5'-CCTCG AGGTCGACGGTATC-3'; rev, 5'-GCAGCTCTAGGCTGGGA GTGA-3'. Glast::CreERT2 mice were crossed with Vegfr $3^{\text {lox/lox }}$ mice to obtain Glast::CreERT2, Vegfr $3^{\text {lox/+ }}$ animals and were mated with Vegfr $3^{10 x / l o x}$ mice to generate Glast::CreERT2, Vegfr $3^{\text {lox/lox }}$ knockout mice. Tx was dissolved in corn oil (Sigma, C-8267) and injected intraperitoneally at $1 \mathrm{mg}$ per day twice daily for $5 \mathrm{~d}$. Animals were sacrificed $7 \mathrm{~d}$ later. The two brain hemispheres were separated: One was used to assess recombination of Vegfr3 locus by immunolabeling with anti-VEGFR-3 Abs on paraffin sections, and the other was used to examine neurogenesis by immunolabeling with anti-GFAP, anti-DCX, anti-BrdU, and anti-KI67 Abs on cryosections. C57Black/6 and OF1 wild-type animals were from Charles River. All animal experiments were performed according to the European Community Council guidelines (88/609/EEC).

\section{BrdU incorporation}

For labeling of LRCs, 2-mo-old Vegfr3::YFP mice were pulselabeled by administering BrdU (Sigma) at $1 \mathrm{mg} / \mathrm{mL}$ with glucose $(10 \mathrm{mg} / \mathrm{mL})$ in drinking water continuously for $4 \mathrm{wk}$. Mice were sacrificed after a BrdU chase of $4 \mathrm{wk}$, and vibratome brain sections were immunostained with anti-BrdU Ab. For analysis of AAV-treated and anti-VEGFR-3-treated animals and Brn4::Cre, Vegfr $3^{\text {lox/lox }}$ mice, the animals to be sacrificed at day 2 received one intraperitoneal injection of BrdU at $150 \mathrm{mg}$ per kilogram of body weight, while the animals to be sacrificed at day 21 received BrdU $75 \mathrm{mg}$ per kilogram of body weight twice per day the day of virus infusion and the next day.

\section{$\beta$-Galactosidase staining}

Animals were anaesthetized intraperitoneally with $1 \mathrm{v}: \mathrm{v}$ of $1 \%$ acepromazine (Centravet) and 5\% ketamine chlorydrate (Mérial) and were perfused with cold $4 \%$ PFA/PBS. Brains were removed and post-fixed for up to $3 \mathrm{~h}$. After embedding in $4 \%$ agarose/ phosphate-buffered saline (PBS), they were sectioned at $50 \mu \mathrm{m}$ with a vibrating blade microtome (Leica VT1200S). Sections were immersed in $10 \mathrm{mM}$ Tris- $\mathrm{HCl}(\mathrm{pH} 7.3)$ containing $0.005 \%$ Na-desoxycholate, $0.01 \%$ nonidet P40, $5 \mathrm{mM} \mathrm{K}{ }_{4} \mathrm{Fe}(\mathrm{CN})_{6}, 5 \mathrm{mM}$ $\mathrm{K}_{3} \mathrm{Fe}(\mathrm{CN})_{6}, 2 \mathrm{mM} \mathrm{MgCl}_{2}$, and $0.8 \mathrm{mg} / \mathrm{mL}$ 5-bromo-4-chloro3 -indolyl b-D-galactopyranoside (X-gal) (Sigma) at $37^{\circ} \mathrm{C}$ until the 
blue precipitate was clearly visible. Sections were air-dried, then transferred to xylene and mounted with Eukitt reagent (Prolabo).

\section{Immunohistochemistry}

Mice were perfused with $4 \%$ paraformaldehyde (PFA), and then post-fixed for $3 \mathrm{~h}$ in the same fixative. Brain coronal cryosections (12 $\mu \mathrm{m}$ thick) or vibratome sections (80 $\mu \mathrm{m}$ thick) were incubated for $2 \mathrm{~h}$ in a solution of $10 \%$ heat-inactivated fetal calf serum (FCS) in PBST (0.1\% Triton X-100 in PBS), then incubated with the primary $\mathrm{Ab}$ (listed in Supplemental Table 1) diluted in PBST-SVF overnight at $4^{\circ} \mathrm{C}$. After washing in PBST, sections were treated with $1.5 \% \mathrm{H}_{2} \mathrm{O}_{2}$ in PBST for $30 \mathrm{~min}$ at room temperature, thoroughly rinsed in PBST (four times for $5 \mathrm{~min}$ ) and incubated with the indicated biotin-conjugated secondary $\mathrm{Ab}$ diluted in PBST, for $2 \mathrm{~h}$ at room temperature. VectastainElite-ABC reagent (Vector Laboratories) was applied for $1 \mathrm{~h}$ and

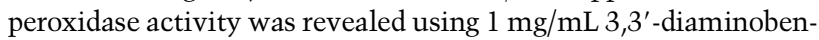
zidine tetrahydrochloride in $0.1 \mathrm{M}$ Tris- $\mathrm{HCl}$ (pH 7.6) (Dakopatts). Sections were dehydrated and mounted with Eukitt. For indirect immunofluorescence labeling, cryosections were blocked in with $10 \%$ FCS. Sections were incubated with primary Abs overnight at $4^{\circ} \mathrm{C}$, rinsed in PBST, and incubated with the indicated fluorochrome-conjugated secondary $\mathrm{Ab}$ for $1 \mathrm{~h}$ at room temperature, followed by three washes of $20 \mathrm{~min}$ each in PBST. All samples were counterstained in $1 \mu \mathrm{g} / \mathrm{mL}$ Hoechst (Sigma) in PBS, and mounted in Fluoromount (Clinisciences).

For double labeling with $\beta$-Galactosidase, the X-Gal reaction was performed before the immunohistolabeling. Detection of VEGFR-3 in the brain was carried out on either vibratome sections with the anti-VEGFR3-Bio Ab (R\&D), or paraffin sections with the anti-VEGFR-3 Ab (sc-321, Santa Cruz Biotechnology, Inc.). Whole-mount immunolabelings of retina, skin, and mesentery with endothelial cell markers were performed as reported ( $\mathrm{Xu}$ et al. 2010). Images were acquired on a Zeiss microscope Imager $\mathrm{Z} 1$ with Axiovision release 4.7 software.

\section{Electron microscopy}

Mice were perfused with $4 \%$ PFA plus $0.5 \%$ glutaraldehyde in $0.1 \mathrm{M}$ phosphate buffer (PB), and post-fixed overnight with $4 \%$ PFA in PB. Vibratome sections $(50 \mu \mathrm{m})$ were washed in $\mathrm{PB}$, cryoprotected in $25 \%$ saccharose, and freeze-thawed (three times) in $-60^{\circ} \mathrm{C}$ methyl-butane. Sections were washed in $\mathrm{PB}$, blocked in $0.3 \%$ bovine serum albumin (BSA)-C (Aurion), and incubated in primary chicken anti-GFP Ab (1:200; Aves Laboratories) for $3 \mathrm{~d}$ at $4^{\circ} \mathrm{C}$. Sections were washed in $\mathrm{PB}$, blocked in $0.5 \%$ BSA and $0.1 \%$ fish gelatin for $1 \mathrm{~h}$ at room tempeture, and incubated in colloidal gold-conjugated anti-chicken secondary $\mathrm{Ab}(1: 50)$ for $24 \mathrm{~h}$. After washing the sections in $\mathrm{PB}$ and $2 \%$ sodium acetate, silver enhancement was performed (Aurion), and sections were washed again in $2 \%$ sodium acetate. Sections were immersed in $0.05 \%$ gold chloride for $10 \mathrm{~min}$ at $4{ }^{\circ} \mathrm{C}$, washed in sodium thiosulfate, washed in $\mathrm{PB}$, and post-fixed with $2 \%$ glutaraldehyde in $\mathrm{PB}$ for $30 \mathrm{~min}$. Sections were post-fixed with $1 \%$ osmium and $7 \%$ glucose and embedded in Durcupan resin (Fluka). Semithin $1.5-\mu \mathrm{m}$ sections were cut with a diamond knife, selected under the light microscope, and re-embedded for ultrathin sectioning at $70 \mathrm{~nm}$. Photomicrographs were obtained under a Fei microscope (Tecnai-Spirit) using a digital camera (Morada, Soft-Imaging System).

\section{Volocity 3D imaging}

Three-dimensional confocal images were acquired on a series of vibratome coronal sections of Vegfr $3:: Y F P$ brains (three or more sections per brain, $n=3$ brains). All images were taken in the lateral ventricular wall facing the striatum at a $40 \times$ magnification and imported into the Volocity 3D imaging software (PerkinElmer Inc.). We used a segmentation method based on intensity criteria for each channel separately, and a 3D watershed algorithm in Volocity to count the number of cells. The cells were counted for each channel in $3 \mathrm{D}$, with a size exclusion for maximum accuracy. All of the double-stained cells were measured, individualized, and counted as a result of a significant $3 \mathrm{D}$ intersection of two specific signals. All of the measurements were based on the raw data and nontreated images in order to faithfully reflect the tissue structure.

\section{Cytometry and immunocytochemistry}

After sacrifice, brains of 2-mo-old Vegfr3::YFP or wild-type mice were removed and kept on ice during dissection. Coronal brain sections were prepared using Acryl Brain Matrix (Phymep). Carefully dissected periventricular zones were treated with papain $\left(0.8 \mathrm{mg} / \mathrm{mL}\right.$; Worthington) for $30 \mathrm{~min}$ at $37^{\circ} \mathrm{C}$ and mechanically dissociated in PBS containing 5\% FCS, $0.3 \%$ glucose, and $5 \mathrm{mM}$ HEPES to obtain a single-cell suspension. To avoid contamination by endothelial cells, periventricular cells were blocked at $4^{\circ} \mathrm{C}$ in PBS containing $5 \%$ FCS, then incubated with anti-CD31-APC Ab diluted (1/200) in PBS $1 \%$ FCS. To isolate EGFR-expressing cells, periventricular cells were incubated successively with anti-CD31-PE Ab (1/200) and EGF647 (1/100, $200 \mu \mathrm{g} / \mathrm{mL}$; Invitrogen) for $30 \mathrm{~min}$. Ten adult brains yielded $\sim 2 \times 10^{5}$ FACS-sorted neural CD31 ${ }^{-} \mathrm{YFP}^{+}$cells. For FACS analysis, cells were fixed with $4 \%$ PFA for $15 \mathrm{~min}$, permeabilized with PBS containing 5\% FCS and $0.1 \%$ Triton $\mathrm{X}-100$, and incubated with primary $\mathrm{Ab}\left(1 \mu \mathrm{g}\right.$ for $10^{6}$ cells $)$ or isotype immunoglobulin control for $30 \mathrm{~min}$ at room temperature. After washing in PBS containing $1 \%$ FCS and $0.1 \%$ Triton $\mathrm{X}-100$, cells were labeled with fluorochrome-coupled secondary Abs (Invitrogen) for $30 \mathrm{~min}$ at room temperature.

For FACS sorting experiments, we used a BD-FACS Aria with a $100-\mu \mathrm{m}$ nozzle aperture. Gates were set according to control samples and data were analyzed with Flow-Jo analysis software.

\section{Cell cultures}

FACS-sorted cells were plated at $2 \times 10^{4}$ to $4 \times 10^{4}$ cells per well in 24-well plates. Neurospheres were grown in Complete Culture Medium (CCM; DMEM/F12-glutamax [Gibco], $20 \mu \mathrm{g} / \mathrm{mL}$ insulin [Sigma], 1/200 B-27 supplement [Gibco], 1/100 N-2 supplement [Gibco], 0.3\% glucose, $5 \mathrm{mM}$ HEPES, $100 \mathrm{U} / \mathrm{mL}$ penicillin/streptomycin) enriched with $20 \mathrm{ng} / \mathrm{mL}$ bFGF and 20 $\mathrm{ng} / \mathrm{mL}$ EGF (both from Peprotech) for $8 \mathrm{~d}$ in vitro. To analyze cell differentiation, whole neurospheres were plated onto Matrigelcoated glass coverslips in CCM without EGF/bFGF for $5 \mathrm{~d}$ in vitro. For self-renewing assays, cells were passaged every $8 \mathrm{~d}$ in vitro at the same $2.10^{4}$-cell-per-well density, and neurosphere formation was scored by counting the number of neurosphere cells. For stimulation with VEGFs, cells were plated in CCM containing EGF and bFGF alone or with recombinant rat VEGF-A or VEGF-C (50 ng/mL; Reliatech). For blocking VEGFR-3 function, rat 31C1-IgG2a Abs $(5 \mu \mathrm{g} / \mathrm{mL})$ were added to FACS-sorted cells cultured in the presence or absence of VEGF-C. For proliferation assays, cells were pulsed with $\operatorname{BrdU}(10 \mu \mathrm{M})$ for $24 \mathrm{~h}$, and fixed after $2 \mathrm{~d}$ in vitro with $4 \%$ PFA in PBS for $15 \mathrm{~min}$ at room temperature. BrdU was revealed by immunofluorescence staining with an anti-BrdU Ab (Roche kit no. 11296736 001). To generate neurosphere cultures directly from SVZ cells, the periventricular zone was dissected out from 300- $\mu$ m Chopper (McILWAIN tissue chopper) sections of postnatal or adult mouse 
brains and trypsinized $(0.5 \mathrm{mg} / \mathrm{mL})$ for $15 \mathrm{~min}$ at $37^{\circ} \mathrm{C}$ to obtain a single-cell suspension. Viable cells counted by Trypan blue exclusion $\left(0.8 \times 10^{5}\right.$ cells per milliliter) were cultured for $10 \mathrm{~d}$ to obtain primary neurospheres. After $7 \mathrm{~d}$ in vitro, the primary neurospheres were dissociated into single cells, which were plated $\left(10^{4}\right.$ cells per well) on Matrigel-coated glass coverslips in 24-well plates in CCM containing EGF and bFGF. Neurosphere cells were cultured with or without VEGF-C $(50 \mathrm{ng} / \mathrm{mL})$ to test the effects of VEGF-C on cell proliferation and survival. For blocking VEGFR-2 function, rat DC101-IgGla Abs $(5 \mu \mathrm{g} / \mathrm{mL})$ were added to FACS-sorted cells cultured in the presence or absence of VEGF-A or VEGF-C (50 ng/mL). Quantifications of neurospheres were done after $7 \mathrm{~d}$ in vitro. For survival assays, cells were cultured overnight with or without VEGF-C (50 ng/ $\mathrm{mL}$ ), fixed, and labeled with the TUNEL detection kit (Roche 11 684809910 ) to detect DNA strand breaks.

\section{Quantitative RT-PCR ( $q R T-P C R)$ and PCR}

Total RNA was extracted with RNeasy lipid tissue kit (Qiagen 74804) or NucleoSpin RNA XS (Macherey-Nagel) for sorted cells, and their integrity was controlled on RNA Nano/pico labChips with Agilent Bioalnalyzer (Agilent Technology). One microgram of RNA was reverse-transcribed using $5 \mu \mathrm{g} / \mathrm{mL}$ random primers (Promega), $1.4 \mathrm{UE} / \mu \mathrm{L}$ RNAsin (Promega) and $7 \mathrm{UE} / \mu \mathrm{L}$ of M-MLV reverse transcriptase (Invitrogen) in $50 \mathrm{mM}$ Tris- $\mathrm{HCl}(\mathrm{pH} 8.3), 75$ $\mathrm{mM} \mathrm{KCl}, 3 \mathrm{mM} \mathrm{MgCl} 2$, and $10 \mathrm{mM}$ DTT with $0.33 \mathrm{mM}$ each dNTP (Invitrogen) for $1.5 \mathrm{~h}$ at $42^{\circ} \mathrm{C}$ followed by $5 \mathrm{~min}$ at $65^{\circ} \mathrm{C}$. For qPCR analysis, $1 \mu \mathrm{L}$ of cDNA was used as template in a reaction volume of $25 \mu \mathrm{L}$ per well of a 96-well plate (Abgene, AB600) that contained in $\mathrm{H}_{2} \mathrm{O} 12.5 \mu \mathrm{L}$ of Brillant II SYBR green master mix (Stratagene) and $1.5 \mu \mathrm{L}$ of primers (Vegfr3 fwd, 5'-GCGGTCTGAAAGGAAGACAG-3', and rev, 5' -ACACCAA GCCAAGCTCAAGT-3'; Vegfc fwd, 5' - AGCCCACCCTCAAT ACCAG-3' , and rev, 5'-GCTGCTCCAAACTCCTTCC-3'; $10 \mu \mathrm{M}$ each; Eurofins, MWG). qPCR reaction was performed in a Light Cycler MX3000 (Stratagene) and was analyzed at OD $533 \mathrm{~nm}$. A control cDNA (Gst [glutathione transferase]) was maintained through individual experiments as a calibrator and a $\Delta \mathrm{Ct}$ was calculated. For PCR, $1 \mu \mathrm{L}$ of DNA was used as a template in a $50-\mu \mathrm{L}$ final volume containing $25 \mu \mathrm{L}$ of master mix (Abgene), $18 \mu \mathrm{L}$ of $\mathrm{H}_{2} \mathrm{O}$, and $2 \mu \mathrm{L}$ of primers $(10 \mu \mathrm{M}$ each). Amplification reactions were performed on a Px2 Thermal Cycler (Thermo Electron Corporation).

\section{Microarrays}

mRNAs were extracted from the $\mathrm{YFP}^{+} \mathrm{CD} 31^{-}$and $\mathrm{YFP}^{-} \mathrm{CD} 31^{-}$ cell populations $\left(5 \times 10^{5}\right.$ cells $)$ obtained from one FACS sorting requiring 10 mice and performed separately three times to obtain triplicate RNA for each cell population. Cells were frozen and homogenized in Trizol (Invitrogen), and RNAs were isolated following the manufacturer's protocol. Purified RNA was dissolved in RNase-free water (Ambion). Concentration was measured using NanoDropH (NanoDrop), and analysis of RNA integrity was performed using the Agilent 2100 RNA Bioanalyzer (Agilent Technologies) using the Pico kit (Agilent Technologies). Fluorescently labeled cRNA targets were generated from 5 ng of poly $(\mathrm{A})^{+}$RNA, using the Low RNA Input Fluorescent Linear Amplification (LRIFLA) kit. RNA samples were reversetranscribed to produce double-stranded cDNA templates, followed by $\mathrm{T} 7$ polymerase-driven in vitro transcriptions to synthetize cDNA targets. Cyanine5-labeled cytidine triphosphates (CTPs) were incorporated into the cRNA targets during the synthesis. Amplification and labeling efficiency was controlled using a NanoDrop. Labeled cRNA was hybridized to ADN
Agilent 44K microarrays per the manufacturer's protocol. After hybridization for $17 \mathrm{~h}$, the arrays were washed and scanned using an Agilent scanner, and microarray data were extracted with Agilent Feature Extraction software. Hybridizations were performed in triplicates. Extracted data were transformed to log base 2. Transformed data were selected by elimination of values $<7$ and of all genes with incomplete values (values $<6$ ).

\section{ELISA}

Protein extracts from the indicated tissues were lysed with RIPA buffer $(50 \mathrm{mM}$ Tris- $\mathrm{HCl}$ at $\mathrm{pH} 8.0,150 \mathrm{mM} \mathrm{NaCl}, 0.5 \%$ deoxycholate acid, $1 \%$ NP-40, $0.1 \%$ sodium dodecyl sulfate) containing protease inhibitor cocktail (Roche). These lysates were used to detect VEGF-C with an ELISA kit (Bender MedSystems, BMS626) according to manufacturer's protocol. Measurement of the color readout was performed at $450 \mathrm{~nm}$ with a multiscan microplate reader (Thermo Electron Corporation).

\section{Viral constructs}

Recombinant AAV (rAAV) vectors encoding VEGF-C (Karkkainen et al. 2001), VEGF-A, and HAS or EGFP were described (Pajusola et al. 2005). The titers were $5 \times 10^{11}$ to $5 \times 10^{12} \mathrm{gp} / \mathrm{mL}$. The expression of AAV-expressed VEGF-A and VEGF-C was verified by transducing HeLa cells with the rAAVs, followed by coprecipitation with the respective receptor Ig molecules (VEGFR-1-Ig or VEGFR3-Ig) from the supernatant, and the resultant protein complexes were separated in SDS-PAGE electrophoresis (data not shown).

\section{Stereotaxic intracerebral injections}

Animals (8-wk-old male C57/Black/6 or Vegfr3::YFP) were anaesthetized intraperitoneally with $0.2 \%$ xylazine (Bayer Health Care) and $1 \%$ ketamine in $0.9 \% \mathrm{NaCl}$ and received intrastriatal virus infusion. The site of infusion was visualized by injection of $0.1 \%$ lissamine (Sigma). A $25-\mu \mathrm{L}$ gauge Hamilton syringe adapted to a KDS100 syringe pump (Kd Scientific) was linked to a glass capillary (Harvard Apparatus, 30-0041) that was surgically implanted at the following coordinates to the bregma: anteroposterior, 0.5; mediolateral, 1.0; and dorsoventral, $2.1 \mathrm{~mm}$. One microliter of AAV-VEGF-C, AAV-VEGF-A, or controls AAVHSA and AAV-EGFP (AAV-ctl) was infused at a flow rate of 0.97 $\mu \mathrm{L} / \mathrm{min}$. Animals treated with a function-blocking $\mathrm{Ab}$ against VEGFR-3 (31-C1 Ab, rat IgG2a anti-VEGFR-3 mAb) were anaesthetized the same way. Anti-VEGFR-3 and control rat IgG2a isotype Abs (3 mg/kg per day) were delivered with a microosmotic Alzet pump (model 1007D) at a rate of $0.5 \mu \mathrm{L} / \mathrm{h}$ for $6 \mathrm{~d}$ above the $1 \mathrm{v}$ of adult Vegfr $3::$ YFP mice (anteroposterior, 0.5 ; mediolateral, 1.0; and dorsoventral, $0 \mathrm{~mm}$ ).

\section{Image acquisition}

Image acquisition was performed using Olympus FV1000 or Leica SP2 AOBS confocal laser-scanning microscopes with 405$\mathrm{nm}$ and 4730nm laser diodes, an Ar laser, and two HeNe lasers (543 $\mathrm{nm}$ and $633 \mathrm{~nm})$.

\section{Quantification and statistics}

The data were analyzed using unpaired Student's $t$-test. For all results, $n$ indicates the number of independent experiments performed. In all histograms, asterisks correspond to $P \leq 0.05$ $\left({ }^{\star}\right), P \leq 0.005\left(^{\star \star}\right), P \leq 0.001\left(^{\star \star \star}\right)$. 


\section{Acknowledgments}

We thank U. Maskos (Pasteur Institute), C. Martin (SEAT), A.-L. Joskowiak (Inserm, UMR-S 975), and C. Blanc (Flow Cytometry Core of Pitié-Salpétrière Hospital) for technical help, and A. Prochiantz (Collège de France) and P.-M. Lledo (Pasteur Institute) for stimulating discussions. C.-F.C. contributed in vitro studies and AAV experiments, R.H.F. contributed AAV experiments and generation and analysis of conditional Vegfr3 mutant, and J.S. contributed generation and analysis of Vegfr3::YFP transgenic mouse. This work was supported by Inserm (J.-L.T. and A.E.), ANR 06-Neuro-034-01 (J.-L.T. and A.E.), Assistance Publique des Hopitaux de Paris (J.-L.T. and A.E.), Neuropôle de Recherche Francilien NeRF (R.H.F.), Ecole des Neurosciences de Paris (J.-L.T.), Fondation Bettencourt (A.E.), NIH (K.A.), Academy of Finland (K.A.), ARSEP (J.-L.T.), and the Finnish Cancer Organizations (K.A.). T.T. was supported by the Helsinki University Central Hospital and the Finnish Academy of Sciences. J.S was a fellow of Boehringer Ingelheim Fonds and FRM.

\section{References}

Acker T, Beck H, Plate KH. 2001. Cell type specific expression of vascular endothelial growth factor and angiopoietin-1 and -2 suggests an important role of astrocytes in cerebellar vascularization. Mech Dev 108: 45-57.

Bock F, Onderka J, Dietrich T, Bachmann B, Pytowski B, Cursiefen C. 2008. Blockade of VEGFR3-signalling specifically inhibits lymphangiogenesis in inflammatory corneal neovascularisation. Graefes Arch Clin Exp Ophthalmol 246: 115-119.

Carmeliet P. 2005. Angiogenesis in life, disease and medicine. Nature 438: 932-936.

Cesetti T, Obernier K, Bengtson CP, Fila T, Mandl C, HolzlWenig G, Worner K, Eckstein V, Ciccolini F. 2009. Analysis of stem cell lineage progression in the neonatal subventricular zone identifies $\mathrm{EGFR}^{+} / \mathrm{NG}^{-}$cells as transit-amplifying precursors. Stem Cells 27: 1443-1454.

Choinacki AK, Mak GK, Weiss S. 2009. Identity crisis for adult periventricular neural stem cells: subventricular zone astrocytes, ependymal cells or both? Nat Rev Neurosci 10: 153163.

Doetsch F, Caille I, Lim DA, Garcia-Verdugo JM, Alvarez-Buylla A. 1999. Subventricular zone astrocytes are neural stem cells in the adult mammalian brain. Cell 97: 703-716.

Ferrara N, Kerbel RS. 2005. Angiogenesis as a therapeutic target. Nature 438: 967-974.

Ferrara N, Gerber HP, LeCouter J. 2003. The biology of VEGF and its receptors. Nat Med 9: 669-676.

Galland F, Karamysheva A, Pebusque MJ, Borg JP, Rottapel R, Dubreuil P, Rosnet O, Birnbaum D. 1993. The FLT4 gene encodes a transmembrane tyrosine kinase related to the vascular endothelial growth factor receptor. Oncogene 8: 1233-1240.

Garcia AD, Doan NB, Imura T, Bush TG, Sofroniew MV. 2004. GFAP-expressing progenitors are the principal source of constitutive neurogenesis in adult mouse forebrain. Nat Neurosci 7: 1233-1241.

Gonzalez-Perez O, Quinones-Hinojosa A. 2010. Dose-dependent effect of EGF on migration and differentiation of adult subventricular zone astrocytes. Glia 58: 975-983.

Gonzalez-Perez O, Romero-Rodriguez R, Soriano-Navarro M, Garcia-Verdugo JM, Alvarez-Buylla A. 2009. Epidermal growth factor induces the progeny of subventricular zone type B cells to migrate and differentiate into oligodendrocytes. Stem Cells 27: 2032-2043.
Haigh JJ, Morelli PI, Gerhardt H, Haigh K, Tsien J, Damert A, Miquerol L, Muhlner U, Klein R, Ferrara N, et al. 2003. Cortical and retinal defects caused by dosage-dependent reductions in VEGF-A paracrine signaling. Dev Biol 262: 225-241.

Haiko P, Makinen T, Keskitalo S, Taipale J, Karkkainen MJ, Baldwin ME, Stacker SA, Achen MG, Alitalo K. 2008. Deletion of vascular endothelial growth factor C (VEGF-C) and VEGF-D is not equivalent to VEGF receptor 3 deletion in mouse embryos. Mol Cell Biol 28: 4843-4850.

Heydemann A, Nguyen LC, Crenshaw EB III. 2001. Regulatory regions from the Brn4 promoter direct LACZ expression to the developing forebrain and neural tube. Brain Res Dev Brain Res 128: 83-90.

Jin K, Zhu Y, Sun Y, Mao XO, Xie L, Greenberg DA. 2002. Vascular endothelial growth factor (VEGF) stimulates neurogenesis in vitro and in vivo. Proc Natl Acad Sci 99: 1194611950.

Joukov V, Pajusola K, Kaipainen A, Chilov D, Lahtinen I, Kukk E, Saksela O, Kalkkinen N, Alitalo K. 1996. A novel vascular endothelial growth factor, VEGF-C, is a ligand for the Flt4 (VEGFR-3) and KDR (VEGFR-2) receptor tyrosine kinases. EMBO J 15: 290-298.

Karkkainen MJ, Saaristo A, Jussila L, Karila KA, Lawrence EC, Pajusola K, Bueler H, Eichmann A, Kauppinen R, Kettunen MI, et al. 2001. A model for gene therapy of human hereditary lymphedema. Proc Natl Acad Sci 98: 12677-12682.

Kriegstein A, Alvarez-Buylla A. 2009. The glial nature of embryonic and adult neural stem cells. Annu Rev Neurosci 32: 149-184.

Le Bras B, Barallobre MJ, Homman-Ludiye J, Ny A, Wyns S, Tammela T, Haiko P, Karkkainen MJ, Yuan L, Muriel MP, et al. 2006. VEGF-C is a trophic factor for neural progenitors in the vertebrate embryonic brain. Nat Neurosci 9: 340-348.

Li Q, Ford MC, Lavik EB, Madri JA. 2006. Modeling the neurovascular niche: VEGF- and BDNF-mediated cross-talk between neural stem cells and endothelial cells: an in vitro study. J Neurosci Res 84: 1656-1668.

Licht T, Eavri R, Goshen I, Shlomai Y, Mizrahi A, Keshet E. 2010. VEGF is required for dendritogenesis of newly born olfactory bulb interneurons. Development 137: 261-271.

Louissaint A Jr, Rao S, Leventhal C, Goldman SA. 2002. Coordinated interaction of neurogenesis and angiogenesis in the adult songbird brain. Neuron 34: 945-960.

Merkle FT, Tramontin AD, Garcia-Verdugo JM, Alvarez-Buylla A. 2004. Radial glia give rise to adult neural stem cells in the subventricular zone. Proc Nat1 Acad Sci 101: 17528-17532.

Merkle FT, Mirzadeh Z, Alvarez-Buylla A. 2007. Mosaic organization of neural stem cells in the adult brain. Science 317: 381-384.

Mirzadeh Z, Merkle FT, Soriano-Navarro M, Garcia-Verdugo JM, Alvarez-Buylla A. 2008. Neural stem cells confer unique pinwheel architecture to the ventricular surface in neurogenic regions of the adult brain. Cell Stem Cell 3: 265-278.

Mori T, Tanaka K, Buffo A, Wurst W, Kuhn R, Gotz M. 2006. Inducible gene deletion in astroglia and radial glia-a valuable tool for functional and lineage analysis. Glia 54: 21-34.

Nagai T, Ibata K, Park ES, Kubota M, Mikoshiba K, Miyawaki A. 2002. A variant of yellow fluorescent protein with fast and efficient maturation for cell-biological applications. Nat Biotechnol 20: 87-90.

Nissant A, Bardy C, Katagiri H, Murray K, Lledo PM. 2009. Adult neurogenesis promotes synaptic plasticity in the olfactory bulb. Nat Neurosci 12: 728-730.

Ogunshola OO, Antic A, Donoghue MJ, Fan SY, Kim H, Stewart WB, Madri JA, Ment LR. 2002. Paracrine and autocrine 
Calvo et al.

functions of neuronal vascular endothelial growth factor (VEGF) in the central nervous system. I Biol Chem 277: 11410-11415.

Pajusola K, Kunnapuu J, Vuorikoski S, Soronen J, Andre H, Pereira T, Korpisalo P, Yla-Herttuala S, Poellinger L, Alitalo K. 2005. Stabilized HIF- $1 \alpha$ is superior to VEGF for angiogenesis in skeletal muscle via adeno-associated virus gene transfer. FASEB J 19: 1365-1367.

Pastrana E, Cheng LC, Doetsch F. 2009. Simultaneous prospective purification of adult subventricular zone neural stem cells and their progeny. Proc Natl Acad Sci 106: 6387-6392.

Ruiz de Almodovar C, Lambrechts D, Mazzone M, Carmeliet P. 2009. Role and therapeutic potential of VEGF in the nervous system. Physiol Rev 89: 607-648.

Sanai N, Tramontin AD, Quinones-Hinojosa A, Barbaro NM, Gupta N, Kunwar S, Lawton MT, McDermott MW, Parsa AT, Manuel-Garcia Verdugo J, et al. 2004. Unique astrocyte ribbon in adult human brain contains neural stem cells but lacks chain migration. Nature 427: 740-744.

Schanzer A, Wachs FP, Wilhelm D, Acker T, Cooper-Kuhn C, Beck H, Winkler J, Aigner L, Plate KH, Kuhn HG. 2004. Direct stimulation of adult neural stem cells in vitro and neurogenesis in vivo by vascular endothelial growth factor. Brain Pathol 14: 237-248.

Shen Q, Wang Y, Kokovay E, Lin G, Chuang SM, Goderie SK, Roysam B, Temple S. 2008. Adult SVZ stem cells lie in a vascular niche: a quantitative analysis of niche cell-cell interactions. Cell Stem Cell 3: 289-300.

Shin YJ, Choi JS, Lee JY, Choi JY, Cha JH, Chun MH, Lee MY. 2008. Differential regulation of vascular endothelial growth factor-C and its receptor in the rat hippocampus following transient forebrain ischemia. Acta Neuropathol 116: 517527.

Shin YJ, Choi JS, Choi JY, Cha JH, Chun MH, Lee MY. 2010. Enhanced expression of vascular endothelial growth factor receptor-3 in the subventricular zone of stroke-lesioned rats. Neurosci Lett 469: 194-198.

Sondell M, Sundler F, Kanje M. 2000. Vascular endothelial growth factor is a neurotrophic factor which stimulates axonal outgrowth through the flk-1 receptor. Eur I Neurosci 12: 4243-4254.

Spangrude G), Heimfeld S, Weissman IL. 1988. Purification and characterization of mouse hematopoietic stem cells. Science 241: 58-62.

Storkebaum E, Lambrechts D, Carmeliet P. 2004. VEGF: once regarded as a specific angiogenic factor, now implicated in neuroprotection. Bioessays 26: 943-954.

Tammela T, Zarkada G, Wallgard E, Murtomaki A, Suchting S, Wirzenius M, Waltari M, Hellstrom M, Schomber T, Peltonen $\mathrm{R}$, et al. 2008. Blocking VEGFR-3 suppresses angiogenic sprouting and vascular network formation. Nature 454: 656-660.

Tavazoie M, Van der Veken L, Silva-Vargas V, Louissaint M, Colonna L, Zaidi B, Garcia-Verdugo JM, Doetsch F. 2008. A specialized vascular niche for adult neural stem cells. Cell Stem Cell 3: 279-288.

Wada T, Haigh JJ, Ema M, Hitoshi S, Chaddah R, Rossant J, Nagy A, van der Kooy D. 2006. Vascular endothelial growth factor directly inhibits primitive neural stem cell survival but promotes definitive neural stem cell survival. I Neurosci 26: 6803-6812.

Wittko IM, Schanzer A, Kuzmichev A, Schneider FT, Shibuya M, Raab S, Plate KH. 2009. VEGFR-1 regulates adult olfactory bulb neurogenesis and migration of neural progenitors in the rostral migratory stream in vivo. J Neurosci 29: 87048714.
Xu Y, Yuan L, Mak J, Pardanaud L, Caunt M, Kasman I, Larrivee B, Del Toro R, Suchting S, Medvinsky A, et al. 2010. Neuropilin-2 mediates VEGF-C-induced lymphatic sprouting together with VEGFR3. I Cell Biol 188: 115-130.

Zechner D, Fujita Y, Hulsken J, Muller T, Walther I, Taketo MM, Crenshaw EB III, Birchmeier W, Birchmeier C. 2003. $\beta$-Catenin signals regulate cell growth and the balance between progenitor cell expansion and differentiation in the nervous system. Dev Biol 258: 406-418.

Zhang H, Vutskits L, Pepper MS, Kiss JZ. 2003. VEGF is a chemoattractant for FGF-2-stimulated neural progenitors. J Cell Biol 163: 1375-1384. 


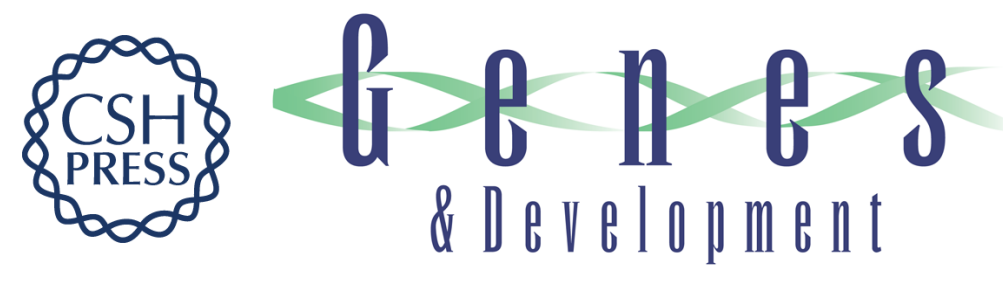

\section{Vascular endothelial growth factor receptor 3 directly regulates murine neurogenesis}

Charles-Félix Calvo, Romain H. Fontaine, Jihane Soueid, et al.

Genes Dev. 2011, 25:

Access the most recent version at doi:10.1101/gad.615311

\section{Supplemental http://genesdev.cshlp.org/content/suppl/2011/04/12/25.8.831.DC1 Material}

References This article cites 48 articles, 13 of which can be accessed free at: http://genesdev.cshlp.org/content/25/8/831.full.html\#ref-list-1

\section{License}

Email Alerting

Receive free email alerts when new articles cite this article - sign up in the box at the top Service 